\title{
Bir Hesap Verebilirlik Teknolojisi Olarak Merkezi Sinavlar: Finlandiya, Estonya ve Yeni Zelanda Örnekleri
}

DOI: 10.26466/opus.592335

\author{
Coskun Erdağ \\ ** Dr. Öğr. Üyesi, Aksaray Üniversitesi, Eğitim Fakültesi, Aksaray / Türkiye \\ E-Posta: coskunerdag79@gmail.com \\ ORCID: $\underline{0000-0002-6173-6340}$
}

Öz

Bu çalışmada, hem batı toplumlarında uygulanan merkezi sınavların doğası, öğrenci performans bilgisinin nasıl üretildiğ i, yayıldı̆̆ ve hangi amaçlarla nasıl kullanıldığıın anlamak ve uygulamalar arası benzerlik ve farkllikkları ortaya koymak, hem de Türk eğitim sisteminin hesap verebilirliği ve öğrencilerin akademik performansların artırma amacıyla merkezi sınavların nasıl kullanılması gerektiğine yönelik bir yaklaşım ortaya koymak amaçlanmıştır. Bu kapsamda, öğrencileri üst düzey akademik performansa sahip olan üç batı toplumunda uygulanan merkezi sınavlar literatürden türetilmiş kavramsal çerçeveye dayalı olarak sistematik bir şekilde incelenmiş ve birbirleriyle kıyaslanmıştır. Bu bağlamda, (i) öğrenci performans bilgilerinin ulusal sınavlarla nasıl üretildiğini, (ii) bu bilginin nasıl yayıldığını ve (iii) eğitim sistemlerinde ne için kullanıldığına ilişkin sorulara cevap aranmıştır. Elde edilen bulgulara göre, daha çok lise düzeyinde Matematik, okuma becerileri, fen bilimleri ve yabancı dil alanlarında merkezi olarak geliştirilmiş ve standartlaştırılmış, çoktan seçmeli, kısa cevaplı, açık uçlu, görev temelli performans değerlendirme ve portfolyo gibi araçlarla güvenirlik tedbirleri alınarak öğrencilerin üst düzey bilişsel performans ölçümleri yapılmakta, elde edilen sonuçlar norm veya ölçüt temelli olarak değerlendirilerek sonuçları eğitim paydaşlarıyla doğrudan paylaşılmakta, öğrenci performans verilerine dayal olarak üretilen bilgi eğitim ve okul sistemi içerisinde özellikle okul yöneticilerinin ve öğretmenlerin öğretimi geliştirmeye yönelik duygu, düşünce ve becerilerini şekillendirecek şekilde kullanılmaktadır. Performans bilgisi okul hesap verebilirliği için kullanıldı̆̆g gibi, öğrenci hesap verebilirliği için de kullanılmaktadır.

Anahtar Kelimeler: Merkezi sınavlar, öğrenci hesap verebilirliği, okul hesap verebilirliği, PISA;

Meta-sentez 


\title{
National Examinations as an Accountability Technology: The Cases of Finland, Estonia and New Zealand
}

\begin{abstract}
The aim of this study is first to determine and compare the western-style policies of national examinations with respect to their production, share and use in primary and secondary schools, and second to discuss the implications for Turkey and develop a policy guide for the use of national examinations in Turkey to ensure both accountability and improvement in the quality of student outcomes. To this end, three Western countries were systematically reviewed and compared based on the literature-derived framework that involves (i) how the student performance information is produced by national examinations, (ii) how this information is disseminated, and (iii) what it is used for in the education systems. Found out that there is a common policy of examination among the top-performing Western nations to produce student performance information in that they both use centrally developed, standardized, normreference, paper and pen exams testing students' high-level cognitive skills in first language, math, science and second language especially at the end of upper secondary schools. Performance information, aggregated or not, is shared with almost all educational stakeholders, and used mainly for student and school accountability purposes.
\end{abstract}

Keywords: National examinations, Student accountability, School accountability, PISA, metasynthesis 


\section{Giriş}

Günümüz küreselleşmiş, rekabetçi ve bilgi tabanlı ekonomi düzeninde var olmaya çalışan toplumların, hem bireylerin yükseköğrenime, mesleki ve sosyal yaşama daha donanımlı bir şekilde hazırlanmaları yönündeki artan beklentileri ve talepleri karşılamak, hem de nitelikli bir iş gücü yaratmak maksadıyla özellikle 1980'lerden sonra test temelli hesap verebilirlik politikalarına sarıldıkları görülmektedir (Bae, 2018; Ball, Junemann ve Santori, 2017; Gable ve Lingard, 2015; Sahlberg, 2016; Tan, 2010; Verger, Parcerisa ve Fontdevila, 2018). Benzer şekilde, Türkiye de eğitimde hesap verebilirlik politikasını ima eden yeni politikaları üç yıl içerisinde hayata geçireceğini "2023 Eğitim Vizyonu" belgesinde ilan etmiştir. Bu belgede Türkiye, öğrencilerin ulusal standartlara göre merkezi olarak izlenmesi ve değerlendirilmesi uygulamasının başlatılacağını, eğitim ve öğrenci performans verilerine dayalı olarak tüm paydaşların katılımıyla eğitime ve okullara ilişkin kararların alınmasına imkan sağlanacağı, bu amaçla mevcut sınav sistemlerinin yeniden yapılandırılacağını ilan etmiştir (Milli Eğitim Bakanlığı [MEB], 2018). Öğrenci kazanımları ve eğitimin niteliği konusunda fen, Matematik, okuma becerileri ve problem çözme becerileri edinimi yanı sıra yabancı dil öğretimi gibi alanlarda ciddi problemleri olan Türkiye'nin (Aydın, Erdağ ve Taş; 2011; Aydın, Sarıer ve Uysal, 2012; Directoraite of Research and Development [EARGED], 2003; 2004; Türkoğlu, 2015), okul hesap verebilirliğine ilişkin kavram ve uygulamaları eğitim sistemi içerisinde yeterince tartışmadığı bir gerçektir. Doğru tartışmalar yapılmadan öğrenci ölçme ve değerlendirme sisteminde yapılacak bir değişikliğin ciddi problemler üretmesi de çok olasıdır. Bu bağlamda, eğitimde yüksek başarıları olan dünya toplumlarının hesap verebilirlik politikalarının anlaşılması, temel kavram ve uygulamalarının belirlenerek tartışılması Türkiye'de hayata geçirilmesi beklenen yeni öğrenci izleme ve değerlendirme sisteminin kuruluşuna ve yönetimine önemli katkı sağlayacaktır. Türkiye, özellikle PISA, TIMSS ve PIRLS gibi uluslararası değerlendirmelerde yüksek performans gösteren diğer eğitim sistemlerinin uygulamaları ve deneyimlerinden yararlanabilir. Tayvan, Hong Kong, Şangay, Singapur, Kore, Japonya ve Vietnam gibi Güneydoğu Asya ülkeleri yanısıra daha farklı felsefe anlayışı ve değerlere 
sahip olan batı kültürleri de önemli hesap verebilirlik tecrübelerine sahiptir. Özellikle Birleşik Devletler, Birleşik Krallık, Avustralya, Yeni Zelanda ve Kanada gibi batı kültürüne sahip ülkeler uzun süredir öğrenci değerlendirmelerine ilişkin önemli tecrübeye sahiptirler. Dolayısıyla, farklı kültürlerin uygulamaya koydukları hesap verebilirlik modelleri ve geliştirdikleri hesap verebilirlik mekanizmalarına dair bilgi, Türkiye'de uygun hesap verebilirlik politikalarının oluşturulması, eğitimin planlanması ve okulların geliştirilmesi husunda eğitim eğitim yöneticilerine ve planlamacılarına önemli katkılar sunacaktır.

Test temelli okul hesap verebilirliği, günümüzde eğitim sorunlarının çözümünde dünyaca kabul gören bir eğitim politikasıdır (Hanushek ve Raymond, 2004; Mundy, 2006). Farklı kültürlerde ve coğrafyalarda uzun zamandır edinilen tecrübelerle geliştirilmektedir. Okul geliştirme ve iyileştirme literatürü, özellikle 1980'lerde ortaya çıkan neo-liberal politikalar ve yeni kamu yönetimi yaklaşımı kapsamında standartlar, yerelleşme, okul özerkliği ve hesap verebilirlik politikalarına büyük önem verildiğini göstermektedir (Ball, Junemann, ve Santori, 2017; Gable ve Lingard, 2015; Sahlberg, 2016; Verger, Parcerisa ve Fontdevila, 2018). Özellikle Birleşik Devletler'de ortaya çıkan hesap verebilirlik kavramı (Robertson, 2015), buradan OECD, Dünya Bankası ve UNESCO gibi uluslararası kuruluşların tavsiyeleri ve teşvikleri ile de Amerika, Asya ve Avrupa ülkelerinde de bnimsenmiştir (Hargreaves, Earl, Moore ve Manning, 2001; Klees, 2008; Sahlberg, 2016). Hesap verebilirlik politikaları yeni kamu yönetimi anlayışı, öğrenci merkezli öğrenme yaklaşımı, eğitim kalitesinin artırılması çabaları ile birlikte hızlı bir şekilde tüm dünyaya yayılmıştır (Verger, Parcerisa ve Fontdevila, 2018). 1960'lı yıllarda insan sermayesini liyakat ve eşitlik temelinde geliştirmeyi amaçlayan öğrenci hesap verebilirliği dünyada hala yaygın olarak kullanılmaktadır (Dorn, 2007). Öte yandan, 1980'lerden sonra eğitimde yaşanılan sorunların kaynağı olarak öğretmenleri ve okul müdürlerini gösteren yeni bir anlayış okul hesap verebilirliğini öğretmenlerin kendilerinden bekleneni ve sorumluluklarını yerine getirmelerini sağlayacak bir çözüm politikası olarak öne çıkarmıştır. 2000'lere gelindiğinde, okul hesap verebilirliği oldukça güçlü bir politika olarak dünya çapında uygulanır olmuş, bu kapsamda öğretmen ve yöneticilerin sorumluluklarına ilişkin formal veya 
informal olarak ödüllendirildiği veya yaptırımlara maruz kaldığı bir dönem ortaya çıkmıştır (Figlio ve Loeb, 2011). En temelde okul hesap verebilirliği politikası, okulların, öğretmenlerin ve okul müdürlerinin eylem ve kararlarının sorumluluğunu almaları ve çevrelerinden gelen beklentilere cevap vermelerini, kurulan güçlü ve sağlıklı hesap verebilirlik ilişkileriyle öğretmenlerin ve okul yöneticilerin uygun davranış göstermelerini sağlamayı amaçlamaktadır (Stecher ve Kirby, 2004). Bu bağlamda okul hesap verebilirliği politikası merkezi sınav ve değerlendirmeler, okul performansinın kamuya duyurulması, ve okul performansı ve gelişim bilgisine göre öğretmen ve yöneticilerin ödüllendirilmesi ve yaptırım uygulanmasını içermektedir (Kane ve Staiger, 2002). Öğrenci hesap verebilirliği ise, aynı anlamda, öğrencilerin belirlenen performanslarına göre ödüllendirilmesi veya yaptırım uygulanmasını içermektedir (Lee ve Wong, 2004).

Levin (1974) okul hesap verebilirliğini bir performans raporlama süreci olarak özetler. Bu bağlamda, okul performans değerlendirmeleri hesap verebilirlik politikasının en temel parçasıdır. İster profesyonel veya performans, isterse piyasa tabanlı okul hesap verebilirlik modeli olsun, öğrencilerin performansları okul hesap verebilirliğinde kilit öneme sahiptir. Okulların performans bilgilerinin standart sınavlarla üretilmesini, ve performans bilgisinin raporlanmasını içerir. Okulun çevresiyle kurulan hesap verebilirlik ilişkisindeki zorlayıcı güç öğrencilerin performans düzeylerinin ve öğretim programının etkililiğinin izlenmesinden kaynaklanmaktadır. Bu anlamda performans raporları önemlidir, çünkü (i) velilere okul performansına ilişkin bilgi verilerek beklentilerinin karşılandığını gösterir (Woessman, 2004), (ii) performans raporlarında beklentilerinin karşılanmadığını gören okul paydaşlarına ise okullar üzerinde baskı üretmelerine olanak sağlar (Ball, 1993; Levin, 1974; Smith ve Rowland, 2014; Woessman, 2007), ve (iii) okul performansı konusunda politika yapıcılarının bilgilendirilmesine, böylece kaynakların doğru bir şekilde yönlendirilmesi ve düşük performans için gerekli desteklerin sağlanmasına olanak sağlar (Joshi ve Smith, 2012; Lincove, 2009). Bu anlamda, öğrenci değerlendirmeleri hükümetlerin ulusal hedeflere ulaşmaları, öğrenme ve öğretim ilkelerine ve standartlarına uygun davranmalarını sağlamak için önemli bir politika aracı olarak hizmet etmektedir (Verger, Parcercisa ve Fontdevila, 2018). 
Okul hesap verebilirliği kapsamında kurulan bürokratik okul hesap verebilirliği modelinde okullar daha çok eğitim süreçlerinden sorumlu tutulurken, profesyonel hesap verebilirlik modelinde ise öğretmenlerin mesleğin gerektirdiği niteliklere sahip olma, mesleki etik ve değerlerine uygun davranma konusunda sorumlu tutulmaktadır. Profesyonel hesap verebilirlikte öğretmenlerin seçimi ve kariyer gelişimlerinde mesleki yetkinlikleri, mesleki gelişimleri, sahip oldukları değerleri ve ahlaki normları belirleyici olurken, öğrenci performans bilgisi öğrencilerin öğrenme sorunları ve çözüm yollarına ilişkin oluşturulur. Bu anlamda, üretilen bilgiler biçimlendirici olup, öğretmen topluluğu içinde belirli normlara dayalı olarak üretilir, mesleki bilgi çerçevesinde değerlendirilir, ve öğretmenlerin içsel motivasyonlarını arttıran bir özelliğe sahiptir (Eurydice, 2009a; O'day, 2002). Performans hesap verebilirliği, bürokratik hesap verebilirliğin aksine, okul sonuçlarına odaklanır, öğrencilerin akademik olarak değerlendirmelerini yapar, okul yöneticilerini ve öğretmenleri öğrencilerin başarı düzeylerinden sorumlu tutar (Bae, 2018). Öğrenci performans değerlendirmeleriyle buna iliştirilen ödül ve yaptırımlarla öğretmenler ve okul müdürleri üzerinde performans baskısı üretilmektedir (Supovitz, 2009). Bu ilişkide, ebeveynlerden daha talepkar ve katılımc1 olmaları, okul müdürlerinin de daha güçlü bir öğretim liderliğiyle öğretmenlerinin motivasyon düzeylerini arttırması beklenmektedir (Holmstrom ve Costa, 1986; Milgrom ve Roberts, 1988). Performans hesap verebilirliğinde, öğrenci başarısına bağlı olarak takdir edilen ödüllerin veya başarısızlık halinde uygulanacak yaptırımların ortaya çıkaracağ öğretmen duygularının okuldaki öğrenme ortamlarını iyileştireceği ve öğrenci kazanım düzeylerini artıracağı varsayılmaktadır (Hanushek ve Raymond, 2004; McDonnell ve Elmore, 1987; Sahlberg, 2016). Öte yandan, piyasa hesap verebilirliğinde öğrenci kazanımları üzerine üretilen bilgi velilerin daha bilinçli kararlar almalarına olanak sağlamakta, okulu seçme özgürlüğü sunmakta, ve okulların birbirleriyle rekabet ederek okul niteliklerinin artmasına ve öğrenci kazanımlarının yükselmesini sağlamaktadır (Figlio ve Loeb, 2011; Rothstein, Jacobsen, ve Wilder, 2008; Olmedo ve Wilkins, 2017). Piyasa hesap verebilirliğinde tercih mekanizmaları ve okul çevresinde okul veya öğretmene ilişkin oluşan iyi veya kötü imaj, okullar ve öğretmenler üzerinde güçlü hesap verebilirlik baskısı üretmektedir (de Wolf ve Janssens, 2007, Harris ve Herrington, 2006). Bu bağlamda, Birleşik 
Devletler'de uygulamaya konulan "Hiçbir Çocuk Geride Kalmasın [NCLB]" düzenlemesi, okulların etkililiğinin sağladıkları katma değere göre belirlenmesini içermekte, öğretime ilişkin standartları, kazanım değerlendirmelerini ve hesap verebilirliği entegre bir şekilde işe koşmaktadır (Datnow ve Park, 2009). Okulların performansları öğrenci değerlendirmelerinden toplanır ve diğer okullarla karşılaştırmalı olarak kamuya bildirilir. Öğrenci performansları, aynı zamanda öğretmenlere ödenecek maaşlar ve ikramiyelerin belirlenmesinde de kullanılmaktadır. Arzu edilen kazanımları gerçekleştiremeyen okullara en fazla üç yıl boyunca destek hizmetleri verilmekte, buna rağmen katma değer üretemeyen okulların insan kaynakları yenilenmektedir (Dillon, 2011; McNeil ve Klein, 2011; Smith ve Rowland, 2014; Springer, 2008). Buna ek olarak, öğrencilerin performans verilerinden elde edilen okul performanslarının karşılaştırılmasıyla elde edilen bilgiler, hem ebeveynlerin karar süreçlerine destek vermekte, hem de okullar üzerinde gelişim baskısı üretmektedir (Smith ve Rowland, 2014).

Tüm bunları dikkate alarak, bu çalışmada akademik performansı yüksek batı ülkelerinde ilkokul, ortaokul ve lise kademelerinde yapılan ulusal düzeydeki standart sınavlarının öncelikle doğasını, öğrenci performans bilgisini bu sınavlarda nasıl ürettiklerini, nasıl yaydıklarını ve hangi amaçlarla nasıl kullandıklarını anlamak ve aralarındaki benzer ve farklı yönleri ortaya koymak amaçlanmaktadır. Buradan hareketle, öğrenci kazanım düzeylerinin artırılmasına hizmet edecek ulusal sınavların oluşturulması ve kullanımına olanak sağlayacak bir politika rehberinin oluşturulması bu çalışmanın ikinci amacıdır. Bu kapsamda, "(i) öğrenci akademik performans bilgileri nasıl oluşturulmaktadır, (ii) öğrenci performans bilgileri kimlerle nasıl paylaşılmaktadır, (iii) öğrenci akademik kazanım bilgisi nasıl kullanılmaktadır, (iv) batı toplumları arasındaki benzerlik ve farklılıklar nelerdir, (v) Türkiye'de merkezi sınavların doğası ve kullanımına ilişkin hangi politikalar izlenmelidir?" sorularına cevap aranmaktadır. 


\section{Yöntem}

\section{Desen}

$\mathrm{Bu}$ çalışma meta-sentez yöntemini merkeze alan karşılaştırmalı bir desende tasarlanmıştır. Bu kapsamda, üst düzey akademik performans sonuçlarına sahip batı toplumlarında uygulamaya konulan merkezi sınavlar üzerine yapılan çalışmaların literatürde tespit edilmesi, uyguladıkları merkezi sınav politikaları üretilen bilginin analiz edilerek sentezlenerek aralarındaki benzerlik ve farklılikların ortaya konulması planlanmıştır. Meta-sentez çalışmaları, özellikle sağlık, sosyal hizmet, örgütsel yaşam (Majör ve Savin-Baden, 2010) gibi alanlardaki kanita dayalı politikaların üretilmesinde yaygın olarak kullanılmakta ve eğitimde kullanımı her geçen gün artmaktadır.

Literatür taraması: Daha çok öğrenci performans bilgisinin oluşturulması, yayılması ve kullanım şekli ve alanlarına odaklı olarak batı toplumlarında uygulanan merkezi sınavlara ilişkin çalışmaları tespit etmek amacıyla kapsamlı bir veri tabanı araştırması yapılmıştır. Bu amaçla Sosyal Bilimler Atıf Endeksi (SSCI), ERIC, Avustralya Akademik Endeksi, İngiliz Eğitim İndeksi, OECD ilibrary, ABI-Inform, Proquest, Lexis-Nexis, JSTOR, and PsycArticles veritabanları ile Google Scholar taranmıştır. Kaynak tarama süreci hem Türkçe hem de İngilizce olarak gerçekleştirilmiştir. Taramalarda "exam", assess*, evaluat", accountability, test* ${ }^{*}$ measurement, standard*, achievement, selection, placement gibi İngilizce anahtar kelimeler yanında "sınav*, değerlendirme*, hesap verebilirlik, test*, ölçüm, standart*, başarı, seçim, yerleştirme" gibi Türkçe anahtar kelimeler de kullanılmıştır. Taramalarda ilgili ülke isimleri Yeni Zelanda, Finlandiya ve Estonya Boolean operatörü olarak kullanılmıştır. Taramalarda kitap, kitap bölümü, makale, ulusal ve uluslararası kurum raporları, dernek raporları, düşünce kuruluşları raporları, ve ulusal eğitim bakanlıklarının web yayınları analize dahil edilmiştir. Veritabanları yanısıra son çalışmaların kullandıkları kaynaklar arasında ilgili olanlara ayrıca ulaşılmıştır. Bu kapsamda gerçekleştirilen başlık ve özet taramasında toplam 511 çalışma incelemeye alınmıştır. 
Dahil Etme / Dışarıda Tutma Kriterleri: Bu meta-sentez çalışmasında literatür taraması ile tespit edilen çalışmaların analize dahil edilmesinde daha çok alakalılık kriteri kullanılmıştır. Buna göre, (i) PISA fen okuryazarlığı değerlendirmelerinde üst sıralarda yer alan toplumlardan, (ii) ilk, orta ve lise kademelerinde ulusal düzeyde gerçekleştirilen merkezi bir sınav programına sahip olan, (iii) sınav geliştirme sürecinin doğasına, (iii) performans bilgilerinin paylaşılmasına, ve (iv) öğrenci performans bilgisinin kullanımına atıfta bulunan, (v) İngilizce veya Türkçe olarak, (vi) 2005 yılı ve sonrasında yayınlanmış herhangi bir rapor, makale, kitap, kitap bölümü veya web içeriği incelemeye dahil edilmiştir. Çalışmaya dahil edilecek ülkeler PISA 2009, 2012, 2015 fen okuryazarlığı sıralamalarına göre en yüksek performans gösteren batı toplumları arasından seçilmiştir. Tablo 1, son üç değerlendirmede en iyi performans gösteren ülkelerin ortalama puanlarını ve sıralarını göstermektedir.

Tablo 1. En başarılı PISA katılımcı ülkelerinin ve Türkiye'nin fen okuryazarlı̆̆ı performansları ve siralamalarn

\begin{tabular}{lccccccc}
\hline \multirow{2}{*}{ Toplumlar } & \multicolumn{2}{c}{ PISA 2009 } & \multicolumn{2}{c}{ PISA 2012 } & \multicolumn{2}{c}{ PISA 2015 } & Toplam \\
\cline { 2 - 6 } & $\begin{array}{c}\text { Ortalama } \\
\text { Puan }\end{array}$ & Sira & $\begin{array}{c}\text { Ortalama } \\
\text { Puan }\end{array}$ & Sira & $\begin{array}{c}\text { Ortalama } \\
\text { Puan }\end{array}$ & Sira & Sira \\
\hline Singapur & 542 & $(3)$ & 551 & $(2)$ & 556 & $(1)$ & $(6)$ \\
\hline Japoya & 539 & $(4)$ & 547 & $(3)$ & 538 & $(2)$ & $(9)$ \\
\hline Finlandiya & 554 & $(1)$ & 545 & $(4)$ & 531 & $(5)$ & $(10)^{*}$ \\
\hline Hong Kong (Çin) & 549 & $(2)$ & 555 & $(1)$ & 523 & $(9)$ & $(12)$ \\
\hline Estonya & 528 & $(8)$ & 541 & $(5)$ & 534 & $(3)$ & $(16)^{*}$ \\
\hline Güney Kore & 538 & $(5)$ & 538 & $(6)$ & 516 & $(11)$ & $(22)$ \\
\hline Kanada & 529 & $(7)$ & 525 & $(9)$ & 528 & $(7)$ & $(23)^{*}$ \\
\hline Tayvan & 520 & $(11)$ & 523 & $(11)$ & 532 & $(4)$ & $(26)$ \\
\hline Yeni Zelanda & 532 & $(6)$ & 516 & $(16)$ & 513 & $(12)$ & $(34)^{*}$ \\
\hline Makao (Çin) & 511 & $(16)$ & 521 & $(15)$ & 529 & $(6)$ & $(37)$ \\
\hline Avustralya & 527 & $(9)$ & 521 & $(14)$ & 510 & $(14)$ & $(37)^{*}$ \\
\hline Almanya & 520 & $(12)$ & 524 & $(10)$ & 509 & $(16)$ & $(38)$ \\
\hline Hollanda & 522 & $(10)$ & 522 & $(12)$ & 509 & $(17)$ & $(39)$ \\
\hline Türkiye & 454 & $(40)$ & 463 & $(41)$ & 425 & $(55)$ & $(136)$ \\
\hline Kaynak: OECD
\end{tabular}

Kaynak: OECD. (2016). Annex B1, Table. I.2.4a

*Fen okur-yazarlı̆̆ında en başarılı ilk beş batı toplumu

Yapılan değerlendirme sonucu ilk etapta Finlandiya, Estonya, Kanada, Yeni Zelanda toplumları incelemeye dahil edilmiş, Kanada'da ülke çapında uygulanan merkezi bir sınav uygulaması bulunmadığından 
incelemenin dışında tutulmuştur. Belirlenen ülkelere ait ulaşılan üretilmiş yayınlardan belirlelen kriter özelliklerini taşıyan ve kaynakçada asteriksle işaretlenen 21 yayın derinlemesine analize alınmıştır. Ulaşılan kaynaklar ve dahil edilme kriterlerine göre değerlendirme süreci akış diyagramı Şekil 1'de gösterilmiştir.

Veri Analizi: Tespit edilen kaynak içerikleri, Majör ve Savin-Baden'in (2010) analiz yöntemi takip edilerek (i) analiz, (ii) sentez, ve (iii) yorumlama olmak üzere üç aşamada analiz edilmiştir. Dahil edilme kriterlerine uyan toplam 21 yayın, ilk olarak bu çalışmanın yazarı tarafından öğrenci değerlendirmeleri ve okul hesap verebilirliği literatürüne dayalı olarak geliştirilen bir çerçeveye dayanarak analiz edilmiştir. Analiz

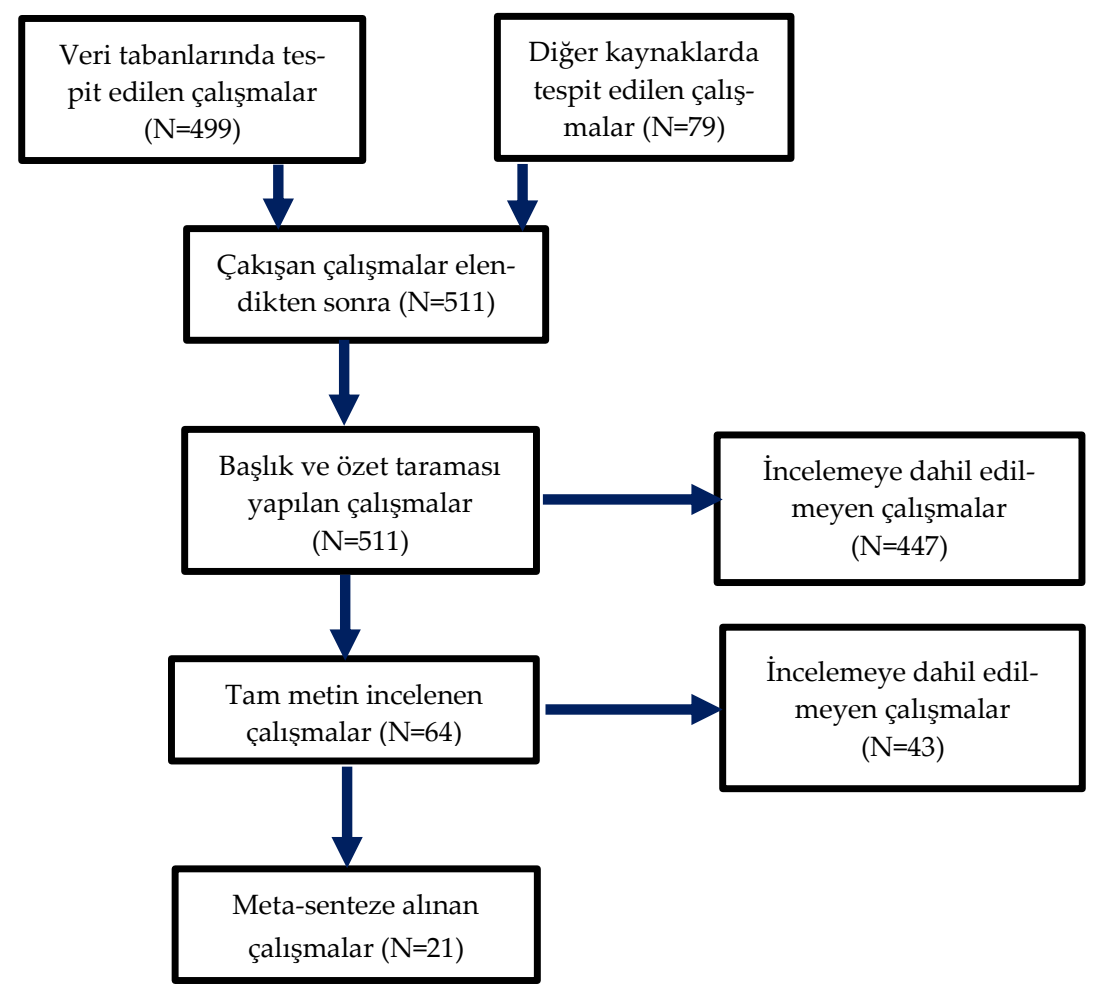

Şekil 1. Ulaşılan kaynakların değerlendirilmesi sürecine ilişkin akış diyagramı 
Bu tema kapsamında, her ülkede (i) merkezi sınavların hangi programlar için sistemin hangi kademelerinde yapıldığı, (ii) sınavın öğrenciler için zorunlu olup olmadığını, (iii) sınavların hangi disiplinlerde yapıldığı, (iv) sınavın geliştirilmesi, standardizasyonu ve puanlanmasında kimin otorite olduğu, (v) işaretleme sürecinin nasıl yönetildiğini, (vi) değerlendirme için kriterin ne olduğunu, (vii) sinav öğelerinin niteliğinin ne olduğunu, (viii) değerlendirmelerde teknoloji kullanılıp kullanılmadığı konularında yayın verileri analiz edilmiştir. İkinci tema, öğrenci performans bilgilerinin paylaşımı ve yayımı ile ilgilidir. Üçüncü tema, performans bilgilerinin hangi amaçlarla kullanıldığı ile ilgilidir. İncelemeye dahil edilen tüm yayınlar daha önce belirlenmiş olan bu analiz çerçevesi etrafında analiz edilmiş ve sentezlenmiştir. Yayın içi ve yayınlar arası çapraz okumalar gerçekleştirerek kodlama ve temalama çalışmasının daha sağlıklı yürütülmesi sağlanmıştır (Noblit ve Hare, 1988).

\section{Bulgular}

\section{Merkezi Sınavların Doğasına İlişkin Bulgular}

Merkezi sınavların doğası: Tablo 2'de ilgili toplumlarda ulusal düzeyde gerçekleştirilen merkezi sınavların farklı kademelerdeki uygulamalarına ilişkin detaylar özetlenmiştir. Buna göre, bu toplumların ilkokul seviyesinde merkezi sınav uygulamasına sahip olmadığı görülmektedir. Sadece Estonya ortaokul seviyesinde merkezi bir sınav uygulamasına sahipken, Finlandiya, Yeni Zelanda ve Estonya lise öğrencileri için merkezi bir sınav uygulaması gerçekleştirmektedir.

Finlandiya'da, 1852'den beri bir olgunlaşma sınavı uygulanmaktadır. Herhangi bir lise programındaki tüm 12. sınıf öğrencileri bu sınava girmek zorundadır. Alan sınavları merkezi yönetim içinde belirlenen standartlara uygun olarak yine merkezi ölçme ve değerlendirme ajansı tarafından hazırlanmaktadır. Öğrenciler Matematik, fen, okuma, yazma ve Edebiyat becerileri, sosyal bilimler, yabancı diller ve beden eğitimi ve sağlık gibi birçok alanda sınava tabi tutulmaktadır. Öğrenci sınav kağıtları kendi öğretmenleri tarafından okunup puanlanmaktadır. Puanlama sürecinde öğrenci puanlarındaki muhtemel öğretmen hataları puanlama kılavuzları ve istatistiki düzenlemelerle etkileri kontrol edilmeye 
çalışılmaktadır. Öğrenci başarısı, öğrencinin okuldaki performansı ve ulusal düzeydeki sıralamasına göre değerlendirilmektedir (Eurydice, 2009a; OECD, 2013; 2015).

Estonya'da hem ortaokul hem de lise düzeyinde ulusal merkezi sinav uygulamaları gerçekleştirilmektedir. Ortaokul 9. sınıf düzeyindeki tüm öğrenciler Ulusal Sınavlar ve Nitelikler Merkezi (NEQC) tarafından hazırlanan standartlaştırılmış sınavlar uygulanmaktadır. Öğrencilerin Matematik, fen, okuma, yazma ve edebiyat becerileri, sosyal bilimler, yabanc1 diller gibi birçok alandaki yeterlilikleri ölçülmektedir. Sorular merkez birim bünyesinde oluşturulan alan komisyonları tarafından hazırlanmaktadır. Sınav puanlaması merkez birimin rehberliğinde ve sıkı denetimi altında okul öğretmenleri tarafından gerçekleştirilmekte, öğrenci sınav puanları önceden belirlenmiş standart kriterlere göre değerlendirilmektedir (Eurydice, 2009b; OECD, 2013; 2015). Liselere gelince, Estonya'daki tüm kamu ve özel lise genel programlarının 12. sınıfında öğrenim gören öğrenciler, 1997'den beri uygulamada olan "Riigeeksam" adlı merkezi bir sınava girmek zorundadırlar. Ulusal eğitim programının amaçlarına parallel olarak merkezi hükümet bünyesinde standartlaştırılan bu sınav merkezi yönetim bünyesindeki ölçme ve değerlendirme birimi tarafından yürütülmektedir Matematik, Estonca/Rusça okuma, yazma ve edebiyat becerileri, yabancı dil alanlarına ait sınav soruları merkezi otorite tarafından geliştirilmekte, puanlama ise okul öğretmenlerince merkezce hazırlanan kılavuza göre sıkı denetim altında gerçekleştirilmektedir. Öğrenci puanları önceden belirlenen öğrenci bilgi ve beceri ölçütlerine göre değerlendirilmektedir (Eurydice, 2009b; OECD, 2013; 2015).

Yeni Zelanda ise, lise eğitiminde daha detaylı bir merkezi sınav sistemine sahiptir. 2002 yılından sonra Yeni Zelanda Yeterlilikler Kurumu (NZQA) tarafindan uygulamaya konulan "Eğitim Kazanımlarının Sertifikasyonu [NCEA]" adlı değerlendirme programı kapsamında öğrenci değerlendirmeleri merkezi olarak yapılmaktadır. Buna göre tüm öğrenciler 11., 12. ve 13. sinıfta aldıkları derslerde elde ettikleri kazanımların ulusal öğretim programı standartlarını karşıladığını göstermek zorundadır. Öğrenciler, NZQA tarafından merkezi olarak geliştirilen ve uygulanan yıl sonu sınavlarının yanı sıra, okuldaki öğretmenleri tarafından yapılan değerlendirmelerde de gerekli niteliklere sahip olduklarını 
göstermek zorundadır. Öğrenciler kariyer tercihlerine göre ders havuzlarından ilgili derslerde eğitim alarak standartları karşıladıklarını bu sinavlarda göstermektedir. Öğrenciler hangi kariyer yolunu takip edeceklerini, hangi dersleri alacaklarını ve hangi sinavlara gireceklerine ilişkin bilgi okulların rehberlik ve danışmanlık hizmetleriyle sağlanmaktadır. Öğrenciler akademik veya mesleki kariyer seçebilecekleri gibi her iki kariyerde de ilerleyebilirler. Öğrenciler hangi diplomayla ilgileniyorlarsa gerektirdiği niteliklere ve standartlara hizmet eden dersleri almak ve sinavlarda yeterlilik göstermelidir. Öğrenci belirli bir standartta yeterli olduğunu göstermek için bu standartla ilgili herhangi bir sınava girebilir. Bununla birlikte, tüm öğrenciler okul sinavlarında veya merkezi sinavlarda temel matematik ve okuma becerilerinde temel standartları karşıladıklarını kanıtlamalıdır. Öğrencilerin hangi yeterliliklere sahip olmaları gerektiğini gösteren öğretim standartları merkezi yönetim tarafından belirlenmektedir. Merkezi ölçme ve değerlendirmeden sorumlu merkezi kurum olan NZQA, ölçme araçlarını geliştirir, bunların uygulanmasını sağlar, puanlamayı yapar, öğrenci puanlarını analiz ederek sonuçlarının ilanını da gerçekleştirir.

Aynı zamanda, NZQA, ölçmenin güvenirliği ve geçerliliğini sağlanması amacıyla her okuldaki ölçümlerin \%10'unu rastgele seçerek analiz etmektedir. Böylece, öğretmenlere puanlama sürecini iyileştirmeleri için geribildirim sağlanmaktadır. Öğrencinin performans puanları ise önceden belirlenmiş başarı düzeylerine göre değerlendirilmektedir (Crooks, 2011; NZMoE, 2010; NZQA, 2018; 2019; OECD, 2013; 2015). Öğretmenler, her öğrenci için ilgili derslerdeki başarılarını Başarısız (N), Yeterli (A), Meziyetli (M) ve İyi Yetişmiş (E) notlarından oluşan 4'lü bir ölçme sisteme göre notlamaktadırlar (NZQA, 2017a, 2017b, 2019a). Ortaöğrenimleri süresince toplanan $\mathrm{M}$ ve $\mathrm{E}$ notlarının sayısı ne kadar yüksek olursa, sonunda sahip olacak olan ders ve diploma başarı düzeyleri de o kadar yüksek olur. Ders notları hem yükseköğretime geçişte hem de istihdamda kullanılmaktadır (NZQA, 2019b). 


\begin{tabular}{|c|c|c|c|c|c|c|c|c|c|c|c|c|c|c|}
\hline \multicolumn{8}{|c|}{ Geliştirilmesi } & \multicolumn{7}{|c|}{ Uygulanması } \\
\hline & & 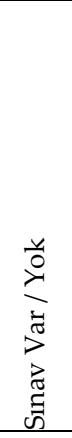 & 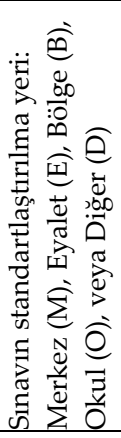 & 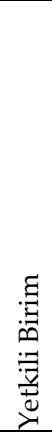 & 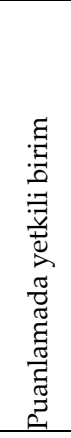 & 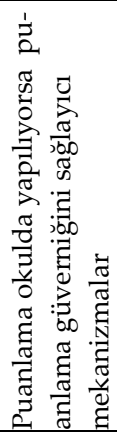 & 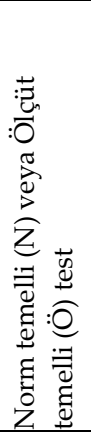 & $\begin{array}{c}\text { Sinav Alanları: } \\
\text { Matematik (MAT), } \\
\text { Fen Bilimleri (FB), } \\
\text { Okuma Becerileri (OB), } \\
\text { Sosyal Bilgiler (SB), Yabancı dil (YD), } \\
\text { Beden eğitimi/sağlık (BE), } \\
\text { Bilgi/İletişim Teknolojileri (BİT), } \\
\text { Teknoloji (TEK), Sanat(SAN), } \\
\text { Din ve Ahlak (DK), } \\
\text { Meslek ve uygulamalı bilimler (MES), } \\
\text { Diğer (D) }\end{array}$ & 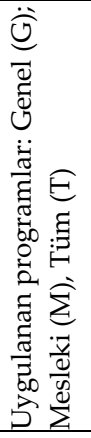 & 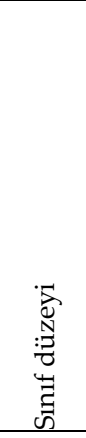 & 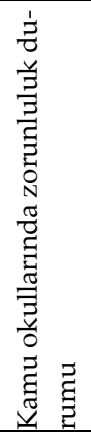 & 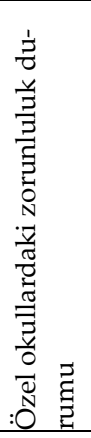 & 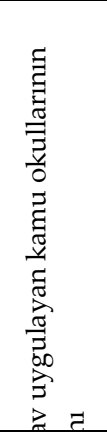 & 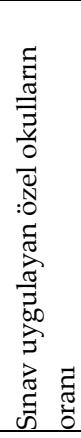 \\
\hline \multirow{4}{*}{ 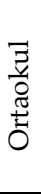 } & Finlandiya & Yok & $\mathrm{a}$ & $\mathrm{a}$ & $\mathrm{a}$ & $\mathrm{a}$ & $\mathrm{a}$ & a & $\mathrm{a}$ & $\mathrm{a}$ & $\mathrm{a}$ & $\mathrm{a}$ & $\mathrm{a}$ & $\mathrm{a}$ \\
\hline & Estonya & Var & $\mathrm{M}$ & 2 & 8 & K & Ö & MAT,FB,OB,SB,YD & $\mathrm{a}$ & 9 & Evet & Evet & $100 \%$ & $100 \%$ \\
\hline & Kanada & Yok & $\mathrm{a}$ & a & a & $\mathrm{a}$ & $\mathrm{a}$ & $\mathrm{a}$ & a & $\mathrm{a}$ & $\mathrm{a}$ & $\mathrm{a}$ & $\mathrm{a}$ & $\mathrm{a}$ \\
\hline & $\begin{array}{l}\text { Yeni } \\
\text { Zelanda }\end{array}$ & Yok & a & a & a & a & a & a & a & a & $\mathrm{a}$ & a & a & a \\
\hline \multirow{4}{*}{$\stackrel{\mathscr{0}}{\exists}$} & Finlandiya & Var & $\mathrm{M}$ & 2,9 & 2 & $\mathrm{~K}, \mathrm{D}$ & $\mathrm{N}$ & MAT,FB,OB,SB,YD,BE,DK & $\mathrm{T}$ & 12 & Evet & Evet & $100 \%$ & $100 \%$ \\
\hline & Estonya & Var & $\mathrm{M}$ & 2 & 2 & $\mathrm{a}$ & Ö & MAT,OB,YD & G & 12 & Evet & Evet & $100 \%$ & $100 \%$ \\
\hline & Kanada & Yok & $\mathrm{a}$ & a & $\mathrm{a}$ & $\mathrm{a}$ & $\mathrm{a}$ & $\mathrm{a}$ & $\mathrm{T}$ & $\mathrm{a}$ & $\mathrm{a}$ & $\mathrm{a}$ & $\mathrm{a}$ & $\mathrm{a}$ \\
\hline & $\begin{array}{l}\text { Yeni } \\
\text { Zelanda }\end{array}$ & Var & M & 2 & $\begin{array}{r}2,8,9 \\
, 10 \\
\end{array}$ & $\mathrm{~K}, \mathrm{D}$ & Ö & $\begin{array}{c}\text { MAT,FB,OB,SB,YD,BE,BİT,TEK,SAN,DK, } \\
\text { MES,D }\end{array}$ & $\mathrm{T}$ & $\begin{array}{c}11,12 \\
13\end{array}$ & Hayır & Hayır & $76-99 \%$ & $\mathrm{~m}$ \\
\hline
\end{tabular}

Kaynaklar: OECD (2013) Table 4.A2.4a,4b, Table 4.A1.4; OECD (2015), Table D6.1a.; OECD (2016) Annex B1, Table II.4.45

Sınavların standartlaştırlması/hazırlanması/Puanlanması/Notlanması - 1: Merkezi otorte-Hükümett, 2: Ölçme ve sertifikasyondan sorumlu merkezi birim, 8: Okul, okul yönetim kurulu, 9: Öğrencinin kendi öğretmeni, 10: Dĭger; a: Uygulanamaz; m: Kayıp

Puanlamanın güvenirliğini sağlayıcı mekanizmalar - K: Merkezi puanlama kılavuzu, D: Düzenleme, O: Diğer

*Ilgili ülkelerde ilkokul düzeyinde merkezi sınav uygulaması bulunmamaktadır. 
Kanada okullarında merkezi sınavlar diğer başarılı ülkelerden farklı olarak ulusal düzeyde yapılmadığı, bunun yerine sinavların eyalet düzeyinde gerçekleştiği ve eyaletin kendine özgü bir sınav uygulaması olduğu görülmektedir (OECD, 2013). Kanada eğitim sisteminde genel ve mesleki eğitim programlarında eyalet yönetimi tarafından belirlenen öğretim programının hedefleri doğrultusunda ilk, orta ve lise düzeyinde merkezi sınav uygulaması mevcuttur. Federal yönetimden bağımsız olarak, her eyaletin kendi yönetim birimi sınavların hangi alanları kapsayacağı, soruların hazırlanması, sınavların uygulanması, puanlanması, değerlendirilmesi ve sonuçlarının ilanı konusunda kendi kararlarını alma ve uygulama özerkliğine sahiptir (OECD, 2013).

Merkezi Değerlendirme Stnavları ve Kullanılan Ölçme Araçlarn: Tablo 3 'te ilgili toplumlarda ilkokul, ortaokul ve liselerde öğrenim gören öğrencilerin ana dil okuryazarlığı, Matematik ve fen bilimleri gibi temel derslerdeki kazanım düzeylerinin nasıl ölçüldüğü ve değerlendirildiğine ilişkin politikaları özetlenmiştir. Finlandiya'da tüm ortaokul öğrencileri ana dil becerileri sınavına girmek zorundadır, ancak Matematik ve Fen sınavlarına katılım öğrencilerin seçimine bırakılmıştır. Finlandiya'da uygulamada olan olgunlaşma sınavı ulusal eğitim hedeflerine dayalı, kalemkağıt türü bir sınavdır. Bu sınavlarda öğrencilerin ana dil becerileri sadece açık uçlu sorular aracılığıyla yoklanırken, fen becerileri ise kısa cevaplı ve açık uçlu sorular aracılı̆̆ıyla yoklanmaktadır. Matematik sınavlarında ise, kısa cevaplı ve açık uçlu sorulara ek olarak çoktan seçmeli sorulara da yer verilmektedir (Eurydice, 2009a; OECD, 2015; 2016).

Estonya'da ortaokulun bitiminde yapılan merkezi sınavda tüm öğrencilerin anadilde okuma ve matematik alanlarında sınava girmeleri zorunluyken, fen bilimleri sınavına katılımları ise öğrenci tercihine bırakılmıştır. Geleneksel bir kalem-kağıt sınavı olan bu uygulamada öğrencilerin okuma ve fen becerilerinin ölçümünde çoktan seçmeli, kısa cevaplı ve açık uçlu sorulara yer verilirken, Matematik becerileri ise görev temelli değerlendirmelerle gerçekleştirilmektedir (Eurydice, 2009b; OECD, 2015; 2016). Benzer şekilde, tüm öğrencilerin lise sonunda ana dil becerileri sinavina katılımları zorunludur, fakat matematik sinavina katılımları tercihe dayalıdır. Lise öğrencilerinin fen becerilerini ölçmek amacıyla ulusal düzeyde bir sınav yapılmamaktadır. Okuma becerilerini 
ölçmek için çoktan seçmeli, kısa cevaplı, açık uçlu soruların yanı sıra görev tabanlı performans değerlendirmeleri de kullanılmaktadır. Matematik becerilerinin ölçümünde ise, yalnızca görev tabanlı değerlendirmeler kullanılmaktadır (Eurydice, 2009b; OECD, 2015; 2016).

Tablo 3. Illkokul*, Ortaokul ve liselerde merkezi sinav uygulamasi yapilan temel dersler, katılım zorunluluğu ve merkezi sınavların temel özellikleri

\begin{tabular}{|c|c|c|c|c|c|c|}
\hline & & \multicolumn{3}{|c|}{ Katılım Zorunluluğu } & \multirow[t]{2}{*}{ Sınavların doğası } & \multirow[t]{2}{*}{ Öğrenci Görevi } \\
\hline & & $\begin{array}{l}\text { Anadil } \\
\text { B. }\end{array}$ & $\begin{array}{c}\text { Mate } \\
\text { B. }\end{array}$ & $\begin{array}{l}\text { Fen } \\
\text { B. }\end{array}$ & & \\
\hline 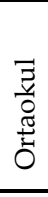 & Estonya & Z & Z & $S$ & $\begin{array}{l}\text { Ulusal öğretim programı } \\
\text { hedefleri temelli öğrencilerin } \\
\text { anadilde okuma, matematik ve } \\
\text { fen bilimleri becerilerini ölçen } \\
\text { kalem-kağıt türü bir sınav }\end{array}$ & $\begin{array}{c}\text { Anadil B: } \\
\text { 1,2,3,5 } \\
\text { Fen: 1,2,3,5 } \\
\text { Mate: } 5\end{array}$ \\
\hline \multirow{3}{*}{$\stackrel{\mathscr{0}}{\beth}$} & Finlandiya & Z & $S$ & $S$ & $\begin{array}{l}\text { Ulusal öğretim programı } \\
\text { hedefleri temelli öğrencilerin } \\
\text { anadilde okuma, matematik ve } \\
\text { fen bilimleri becerilerini ölçen } \\
\text { kalem-kağıt türü bir sınav }\end{array}$ & $\begin{array}{c}\text { Anadil B: } 3 \\
\text { Fen: } 2,3 \\
\text { Mate: } 1,2,3\end{array}$ \\
\hline & Estonya & Z & $S$ & A & $\begin{array}{c}\text { Ulusal öğretim programı } \\
\text { hedefleri temelli öğrencilerin } \\
\text { anadilde okuma, matematik } \\
\text { becerilerini ölçen kalem-kağıt } \\
\text { türü bir sınav }\end{array}$ & $\begin{array}{c}\text { Anadil B: 3,5 } \\
\text { Mate: } 5\end{array}$ \\
\hline & $\begin{array}{l}\text { Yeni } \\
\text { Zelanda }\end{array}$ & S & S & $S$ & $\begin{array}{l}\text { Ulusal öğretim programı } \\
\text { hedefleri temelli öğrencilerin } \\
\text { anadilde okuma, matematik ve } \\
\text { fen bilimleri becerilerini ölçen } \\
\text { kalem-kağıt türü bir sınav }\end{array}$ & $\begin{array}{l}\text { Anadil B: } \\
2,3,4,5,6,7 \\
\text { Fen: } 2,3,5 \\
\text { Mate: } 2,3\end{array}$ \\
\hline
\end{tabular}

Kaynaklar: OECD (2015). Table D6.2b, 2c; OECD (2016)

*Ilgili ülkelerde ilkokul düzeyinde merkezi sınav uygulamasi yoktur.

Katılım zorunluluğu: Zorunlu (Z), Seçmeli (S), Uygulanamaz (A)

1: Çoktan seçmeli, 2: Kısa cevaplı, 3: Açık uçlu, 4: Portfolyo, 5: Görev/Deney, 6: Sözlü sunum, 7: Sözlü yoklama, 8: Problem çözme

Yeni Zelanda'da, lise sınavları zorunlu değildir. Merkezi ölçme ve değerlendirme birimi tarafından hazırlanan sinavlar kalem-kağıt formatında klasik sınav uygulamalarındandır. Okuma becerileri yeterlilik sınavlarında kısa cevaplı, açık uçlu sorular yanı sıra sözlü sunum, mülakat, portfolyo ve görev tabanlı değerlendirme gibi alternatif araçlar 
kullanılmakta, çoktan seçmeli sorulara ise yer verilmemektedir. Matematik ve fen sınavlarında hem kısa cevaplı hem de açık uçlu sorulara yer verilmekte, fen becerileri sınavında ise bunlara ek olarak deney bilgi ve becerilerin ölçümü maksadıyla uygulama sınavlarına da yer verilmektedir (OECD, 2015; 2016).

\section{Sınav Sonuçlarının Paylaşımına İlişkin Bulgular}

Tablo 4'te batı toplumlarındaki ilkokul, ortaokul ve lise öğrencilerinin kazanımlarını ölçmek amacıyla gerçekleştirilen merkezi sınavların sonuç bilgisinin nasıl yayıldığını özetlemektedir.

Buna göre, Finlandiya, Estonya ve Yeni Zelanda otoritelerinin sinav sonuçlarını ve öğrenci performans bilgilerini öğrencilere, velilere, öğretmenlere, okul yönetimine ve ilgili okul dışı birimlere ilettikleri görülmektedir (OECD, 2015; 2016). Ortaokul öğrencilerini merkeze sınava alan Estonya, sınav sonuç raporlarında ortaokulların bir önceki sınav performansları, okul kalitesi ve okul bağlamının niteliğine ilişkin gösterge değerleri, öğrencilerin bağıl sıralamalarını vermektedir.

Tablo 4. Illkokul*, ortaokul ve liselerde uygulanan merkezi sınav sonuçlarının paylaşılması ve yayım metotları

\begin{tabular}{|c|c|c|c|c|c|c|c|}
\hline & & \multicolumn{6}{|c|}{ Paylaşım ve yayım metotları } \\
\hline & & 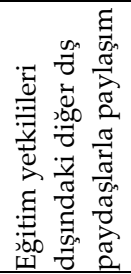 & 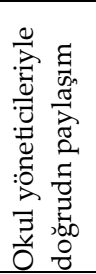 & 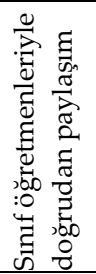 & 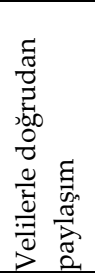 & 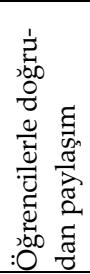 & 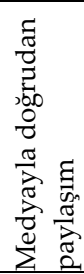 \\
\hline Ortaokul & Estonya & Evet & Evet & Evet & Evet & Evet & Evet \\
\hline \multirow{3}{*}{ Lise } & Finlandiya & Evet & Evet & Evet & Evet & Evet & Evet \\
\hline & Estonya & Evet & Evet & Evet & Evet & Evet & Evet \\
\hline & Yeni Zelanda & Evet & Evet & Evet & Evet & Evet & Evet \\
\hline
\end{tabular}

Kaynaklar: OECD (2015); OECD (2016), Annex B1, Table II.4.45; 46

*ilgili toplumlarda ilkokul düzeyinde merkezi sınav uygulaması bulunmamaktadır.

Diğer taraftan, performans raporlarında okulların öğrenci başarısına sağladıkları katkı düzeyi, okul sıralamaları, okul ödülleri ve yaptırımlar bilgisine ise yer verilmemektedir. 9. sinıf düzeyinde yapılan merkezi 
sınav sonuçları ise, okul bazında analizleri yapılarak öğrenci performanslarında okul türleri, cinsiyetler, dil ve bölgeye göre farklılaşmaların olup olmadığıı, merkezi eğilimin ne olduğu, eğilimin zaman içerisinde nasıl değiştiği üzerine detaylandırılmaktadır. Madde tabanlı analizlerin yanı sıra görev tabanlı analizler de yapılmaktadır. Merkezi otorite tarafından yapılan analiz sonuçları ve üretilen bilgi NEQC web sitesinden ilan edilmekte, tüm paydaşların kullanımına açılmaktadır (Eurydice, 2009b; OECD, 2015).

Finlandiya'da yayınlanan okul raporları sadece okul öncesi başarı düzeyi ve okul genel performansı ile ilgili bilgileri içermektedir (OECD, 2015). Yeni Zelanda'da ise, merkezi sinav sonucunda öğrencilerin kazanımlarına ilişkin bir karne verilmektedir. Bu karne öğrencinin hangi kazanımları edindiği, hangilerini ise edinemediğini gösterir. Bu bilgi öğrenciler, veliler, öğretmenlerin yanı sıra üniversitelerle de paylaşılmaktadır (NZMoE, 2010; NZQA, 2019b). Okul düzeyindeki raporlama ise, okulların öğretim standartlarına ilişkin öğrencilere ne kattığ ve NZQA web sitesi üzerinde eğitim paydaşları ve izleyicilerine sunulmaktadır. Okul düzeyinde üretilen performans bilgisi, okullar arası ve bölgesel performans karşılaştırmalar okul performansının izlenmesine olanak sağlamaktadır. Aynı zamanda, öğrenci ve okul performanslarında öğrenci ve okul demografik özelliklerine bağlı farklılaşmalar da belirlenmeye çalışılmaktadır (NZMoE, 2010). Buna ek olarak, okul performans bilgisi kamu erişimine açıtır, diğer taraftan medya performans bilgilerini işleyerek okul sıralamaları oluşturmakta ve okullar arası performans karşılaştırmaları yaparak ek bilgi olarak kamuya sunmaktadır (Crooks, 2011).

\section{Sınav Sonuçlarının Temel Kullanım Alanları}

İlgili toplumların eğitim sistemlerinde ulusal sınavların hangi amaçlarla kullanıldığı Tablo 5'te özetlenmektedir. Estonya'da ortaokul öğrencilerinin merkezi sınavlarda belirlenen performanslarına dayalı olarak öğrencilerin adaletli bir şekilde mezuniyetlerinin sağlanması, sınıfı geçme ve liselere öğrencilerin yerleştirilmesi kararları verilmektedir (Eurydice, 2009b; MoNE, 2018b; OECD, 2015). Öğrencilerin lisede merkezi sınavlarla belirlenen performansları ise, Finlandiya ve Estonya'da daha çok yüksek 
öğretim programlarına öğrenci seçimi ve yerleştirilmesi kararlarında kullanılmaktadır. Bu ülkelerde merkezi sınavlar aynı zamanda öğrencilerin sınıf geçmelerinde ve mezuniyetlerinde de kullanılmaktadır. Performans sonuçları da kısmen kamuya ve okullara açıktır. Okullar sonuçları aynı zamanda iç değerlendirme ve gelişim süreçleri için de kullanabilir (Eurydice, 2009b; OECD, 2015). Öğrencilerin akademik veya mesleki standart seviyelerini belirlemeyi ve belgelemeyi amaçlayan merkezi sınavlar Yeni Zelanda'da ise lise öğrencilerin üniversiteye seçimi ve yerleştirilmesinde kullanıldığı gibi, mesleki yaşamda öğrencileri işe alımında işverenler tarafından da kullanılmaktadır. Aynı zamanda, Yeni Zelanda öğrenci performans bilgisini öğrencilere verilecek burs ve mali yardımların belirlenmesinde de kullanmaktadır. Ayrıca, öğretmenler öğrencilerinin performansları hakkında sağlanan bilgiye dayanarak öğretimi yeniden planlamalarına, ve ayrıca etkili yöntem ve teknikler geliştirmelerine de olanak sağlamaktadır (NZMoE, 2010). Bu toplumlarda hiçbir öğrencinin sınav performansına göre okuldan atılması hiçbir şekilde söz konusu değildir.

Tablo 5. Ilkokul*, ortaokul ve liselerde uygulanan merkezi sınav sonuçlarının amaçları ve kullanımları

\begin{tabular}{|c|c|c|c|c|c|c|c|c|c|}
\hline & & \multicolumn{8}{|c|}{ Merkezi sınavların temel amaç ve kullanımları } \\
\hline & & 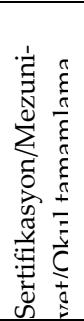 & 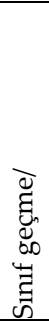 & 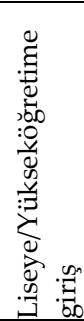 & 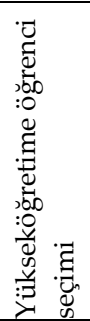 & 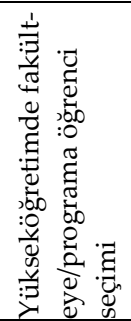 & 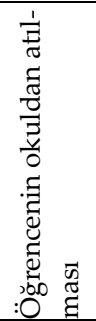 & 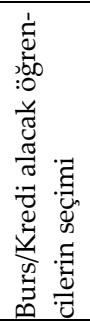 & 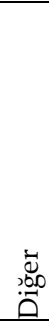 \\
\hline Ortaokul & Estonya & $\mathrm{E}$ & $\mathrm{E}$ & $\mathrm{E}$ & $\mathrm{E}$ & $\mathrm{H}$ & $\mathrm{H}$ & $\mathrm{H}$ & $E$ \\
\hline \multirow{3}{*}{ Lise } & Finlandiya & $\mathrm{E}$ & $\mathrm{H}$ & E & E & $\mathrm{E}$ & $\mathrm{H}$ & $\mathrm{H}$ & $\mathrm{H}$ \\
\hline & Estonya & E & $\mathrm{E}$ & E & E & E & $\mathrm{H}$ & $\mathrm{H}$ & $\mathrm{E}$ \\
\hline & Yeni Zelanda & E & E & E & E & E & $\mathrm{H}$ & E & $\mathrm{H}$ \\
\hline
\end{tabular}

Kaynaklar: OECD (2015); OECD (2016) Annex B1, Table II.4.45; 46

Evet (E); Hayır (H)

*ilgili toplumlarda ilkokul düzeyinde merkezi sinav uygulaması bulunmamaktadır. 


\section{Tartışma, Sonuç ve Öneriler}

Bu çalışmada, PISA sınavlarında sürekli olarak yüksek başarı gösteren üç toplumun eğitim sistemlerinde öğrencilerin performans bilgilerini merkezi sınavlarla nasıl ürettikleri, bu bilgiyi kimlerle paylaştıkları, ve bu bilginin hangi amaçlarla kullanıldığına dair elde edilen bulgular merkezi sınavların doğası ve öğrenci ve okul hesap verebilirliğine katkıları konusunda önemli bilgiler sunmaktadır.

\section{Öğrenci Performans Bilgisinin Üretilmesine İlişkin Benzerlikler ve Farklilıklar}

Finlandiya, Estonya ve Yeni Zelanda'da yapılan merkezi sinavlara bir bütün olarak bakıldığında, bazı hususlarda farklılaştıkları fakat çoğu hususta ortak uygulamalara sahip oldukları görülmektedir. Öncelikle merkezi sınavlar daha çok 15 yaş ve üstü öğrenciler için hazırlanmakta ve ilkokul öğrencilerini kapsamamaktadır. Merkezi sınavlar, merkezi olarak oluşturulmuş ölçme ve değerlendirme birimleri tarafından ulusal öğretim programı hedefleri temel alınarak öğrencilerin daha çok anadilde okuma becerileri, Matematik becerileri, Fen bilimleri becerileri ve yabancı dil becerilerini ölçen kalem-kağıt türü sınavlardır. Sınavlarda öğrencilerin kavrama, analiz, sentez ve problem çözme gibi üst düzey bilişsel becerilerinin ölçümüne odaklanmaktadır. Bu kapsamda çoktan seçmeli sorular yerine daha çok kısa cevaplı, açık uçlu sorular ve sözlü sunum, mülakat, portfolyo ve görev tabanlı değerlendirme gibi alternatif ölçme araçları tercih edilmektedir. Sınavlara katılım konusunda ise, ülkeler farklı politikalar izlemektedir. Yeni Zelanda'da merkezi sinavlara katılım zorunlu tutulmazken, Finlandiya sadece okuma becerileri, Estonya ise hem okuma becerileri hem de matematik becerileri alanlarında öğrencilerin sınavlara katılımın zorunlu tutmaktadır. Diğer alanlarda merkezi sınava katılmak öğrencinin tercihine bırakılmıştır. Uygulama sonrası öğrenci yanıtları hem merkezi yönetim, hem de merkezi yönetimin sıkı rehberliği ve kontrolü altında öğretmenler tarafından titiz bir şekilde puanlanmakta, yine merkezi yönetimce başarı puanları önceden belirlenen kriterlere göre değerlendirilerek öğrenci performans bilgisi üretilmektedir. Öte yandan, 
Yeni Zelanda diğer iki ülkeden sınavların içeriği ve uygulanması açılarından ayrışmaktadır. Yeni Zelanda öğrenci performans bilgisini sadece tek bir vakitte yapılan tek bir ölçüme dayanarak değil, lise öğreniminin son üç yılında hem merkezi otoritenin hazırladığı merkezi sınavlar, hem de öğretmenler tarafından yapılan dönem içi sınavlara dayanarak belirlemektedir. Tüm öğrencilerin öncelikle Matematik ve okuma becerileri performansları belirlenirken, öğrencilerin seçtiği kariyere göre farklı öğrenme alanlarındaki performansları da ölçülmektedir. Finlandiya ve Estonya ise, Yeni Zelanda'dan farklı olarak, öğrencilerinin yabancı dildeki performanslarına ilişkin de bilgi üretmektedir.

Türkiye'deki merkezi sınav uygulamalarına bütüncül olarak bakıldığında, Finlandiya, Estonya ve Yeni Zelanda'daki uygulamalara benzer bir uygulamanın yürütüldüğü görülmektedir. Ortaokul sonunda Liselere Geçiş Sınavı (LGS) olarak adlandırılan ve sadece sınavla öğrenci alan liselere yerleşme amacı olan 8. sınıf öğrencilerin katıldığı merkezi bir sınav uygulaması mevcuttur. Sınav soruları sadece 8. sınıf Türkçe, Matematik, Fen Bilgisi, İngilizce, Din Kültürü ve Ahlak Bilgisi, İnkılap Tarihi öğretim programlarını kapsamakta, Milli Eğitim Bakanlığı merkez yönetim bünyesindeki kurullarca hazırlanarak standartlaştııılmaktadır (Delil ve Tetik, 2015; MEB, 2018). Öğrencilerin kavrama, yorumlama, çıkarsama, problem çözme, analiz ve sentez, eleştirel ve bilimsel düşünme becerilerini ölçmeyi hedefleyen ve sadece çoktan seçmeli maddelere yer verilen sınavların puanlanması ve ölçüte dayalı değerlendirmeleri yine merkez yönetim birimince yapılmaktadır (MEB, 2016; 2018a). Ayrıca öğrenci performansları hesaplanırken merkezi sınav puanına ek olarak öğrencilerin 6., 7. ve 8. sınıf derslerindeki başarıları da performans puanına dahil edilmektedir (Delil ve Tetik, 2015; İncikabı, Kurnaz ve Pektaş, 2013; MEB, 2018; OECD, 2015; 2016).

Benzer olarak, lise son sınıf öğrencilerinin de yaklaşık dörtte üçünden fazlası Türkçe, Edebiyat, Matematik, Fen, Tarih, Coğrafya, Din Kültürü alanlarındaki üst düzey bilişsel becerileri milli eğitim programlarının hedeflerine uygun olarak katılımı zorunlu olmayan kalem-kağıt türü çoktan seçmeli testlerle merkezi olarak ölçülmekte ve norm temelli olarak değerlendirilmektedir (OECD, 2015; 2016; ÖSYM, 2019a). Türkiye'de Temel Yetenek Sinavı ve Alan veya Yabancı Dil Yetenek Sinavı olmak 
üzere iki aşamada gerçekleştirilen bu sinavlara girişler öğrencilerin kariyer tercihlerine bırakılmıştır. Sınavlar idari ve mali özerkliğe sahip özel bütçeli bir kamu kurumu olan Öğrenci Seçme ve Yerleştirme Merkezi (ÖSYM) merkezi tarafından hazırlanarak standartlaştırılmakta, yine aynı merkezce puanlamaları, analizleri ve değerlendirmeleri norm temelli olarak gerçekleştirilmektedir (OECD, 2016; ÖSYM, 2019). Öğrenci başarı sırası hesaplanırken sadece sınav puanı değil, öğrencinin lise başarı ortalaması da hesaba katılmaktadır. Son iki yılda yapılan Yüksek Öğretime Geçiş Sınavı madde yapıları incelendiğinde ise, sadece çoktan seçmeli sorularla öğrencilerin üst düzey analiz, sentez ve değerlendirme boyutlarına yoğunlaşan bir ölçmenin uygulamaya konulduğu gözlenmektedir (Koç, Sönmez ve Çiftçi, 2013).

Buna göre, ülkelerin benzer şekilde (i) ilkokul düzeyinde merkezi sınav uygulamasına yer vermedikleri, daha çok lise düzeyinde merkezi sınavları uyguladıkları, (ii) sinavları merkezi olarak yürüttükleri, (iii) sınav sorularının hazırlanması, standartlaştırılması, puanlanması, değerlendirilmesi ve sonuçların analizi genel olarak yine merkezi yönetim birimleri tarafından gerçekleştirildiği sonucuna ulaşılmaktadır.

\section{Öğrenci Performans Bilgisinin İçeriği, Paylaşımı ve Kullanımına İlişkin Benzerlikler ve Farklılıklar}

Hazırlanan performans raporlarının içeriği ise ülkeden ülkeye değişmektedir. Öğrenci raporlarında, öğrencinin hangi kazanımlara ulaştıkları, hangilerine ise ulaşamadıkları üzerine yoğunlaşılmakta, ve öğrencilerin bağıl sıralamalarına yer verilmektedir. Okula ilişkin hazırlanan raporlarda ise, Finlandiya ve Estonya daha çok okul kalitesi ve okul bağlamının niteliğine ilişkin durumu ile okulların bir önceki ve şimdiki sınav performansların genel anlamda özetlemekte, böylece okulların gelişimi izlenmektedir. Yeni Zelanda ise, okulların program standartlarına ilişkin öğrencilere ne kattığı üzerine bilgi vermekte, öğrenci ve okul performanslarında öğrenci ve okul demografik özelliklerine bağlı farklılaşmaları da gözler önüne sermektedir. Sağlanan detaylı bilgiler sayesinde medya okullar arasında bir sıralama yapma imkanı dahi bulmaktadir. 
Diğer yandan, üretilen öğrenci performansına ilişkin bilgi hem öğrenci hem de okul hesap verebilirliği için kullanılmaktadır. Yeni Zelanda, Finlandiya ve Estonya'da öğrencilerin sınıfı geçme, mezuniyet, yüksek öğretim programlarına yerleşme, burs ve mali yardımlara ulaşmaları ve işe alımlarına ilişkin önemli kararlar öğrenci performans düzeylerine göre alınmakta, bu sayede öğrenciler arasında adalati sağlayan bir araç olarak işlev görmekte ve liyakatı ön plana çıkartmaktadır. Aynı zamanda, öğrenci kazanımlarına ilişkin hazırlanan performans raporları okul hesap verebilirliği için de kullanılmaktadır. Bu ülkeler merkezi sınavlar aracılığıyla üretilen öğrenci performans bilgisini ilgili dış paydaşlarla, medyayla, öğrencilerle, velilerle, öğretmenlerle ve eğitim yöneticileriyle paylaşmakta, onlara sınav sonuçlarına erişim olanağı sağlamaktadır. Böylece okul çevresi okul süreçleri ve sonuçlarına ilişkin temel bilgilere ulaşma ve anlamlandırma imkanına kavuşmakta, beklentilerinin karşılanma düzeyine ilişkin durum tespiti yapma, buna göre doğru tavır ve davranış üretme olanağı bulmaktadır. Hem veli, hem öğretmenler, hem de okul yöneticileri öğretim ortamlarında eğitimin verimliliği ve etkililiğine katkı sağlayacak doğru öğretmen ve yönetici tavır ve davranışlarının geliştirilmesine, bununla birlikte etkili bir okul öğrenme ortamının sağlanmasına olanak sağlamaktadır. Okulların öğretim süreçleri ve sonuçlarına ilişkin problem alanlarının belirlenerek veriye dayalı karar alma ve politika geliştirme sürecini de desteklemektedir. Bu ülkeler öğrencilerin performans bilgilerini çoğunlukla öğrenci ve okul özelinde öğretime dair kararların alınması ve gelişim politikalarının üretilmesinde kullanmaktadır.

İkinci olarak, merkezi sınavlar okullarla ile iç ve dış çevre arasında etkili hesap verebilirlik ilişkilerinin kurulmasına da olanak sağlamaktadır. Öğrenci performans bilgisini üretip çevreye yayarak eğitim sistemi üzerinde çoklu kontrol sağlanması amaçlanmaktadır (Best, Knight, Lietz, Lockwood, Nugroho ve Tobin, 2013). Bazı ülkeler öğretim uygulamalarını izlemek ve kontrol etmek için performans ve piyasa hesap verebilirliğini tercih ederken, bazıları profesyonel hesap verebilirlik yaklaşımı ilkelerini uygulamaktadır. Finlandiya, Estonya ve Yeni Zelanda istisnasız öncelikle profesyonel hesap verebilirlik yaklaşımını izlemekte, performans bilgisi okul ve öğretmenler için kıymetli bir geribildirim olarak görülmektedir. Alınan geribildirimin öğretmenlerin motivasyonlarının ve kapasitelerinin 
gelişimine katkı sağlaması, böylelikle okullarda etkili bir öğrenme ortamı ve iklimi geliştirilerek okulların ve dolayısıyla öğrencilerin öğrenmelerine katkı sağlanması amaçlanmaktadır. Yeni Zelanda'da profesyonel hesap verebilirlik çok güçlü bir şekilde uygulanmaktadır. Ö̆ğretim standartlarına göre oluşturulmuş öğrenci performans verileri öğrenci performansının geliştirilmesi, öğrenme güçlüğü çeken veya risk altındaki öğrencilerin belirlenmesi, uzman ve ebeveyn desteği sağlanması, günlük öğretim ortamlarında ve etkinliklerde ihtiyaç duyulan değişimlerin gerçekleştirilmesinde güçlü bir rehberlik sunmaktadır. Öğrenci performans bilgisi öğrencilerin öğrenmelerini desteklemesi için veli ve öğrencilerle de paylaşılmaktadır. Okul idareleri ise, okulun güçlü ve zayıf yönlerinin farkına vararak öğretimi yeniden düzenlemek ve geliştirmek için performans bilgisinden yararlanmaktadır.

Öte taraftan, Finlandiya ve Estonya'nın tersine yalnızca Yeni Zelanda öğrenci performans bilgilerine dayanan pazar ve performans tipi okul hesap verebilirlik yaklaşımlarını tercih etmektedir. Yeni Zelanda, merkezi değerlendirmelerle kendi öğrenci performanslarına ilişkin okul düzeyinde bilgi üretmekte, daha sonra web sayfalarında yayınlayarak ilgili eğitim paydaşlarına değerlendirmeye ilişkin veri ve bilgilere erişim olanağı sunmakta, zaman içerisinde okul performansının gelişiminin izlenmesine izin vermektedir. Ayrıca, tüm paydaşlar ve medya, bölgesel veya ülke genelinde, farklı alanlarda veya alt gruplardaki performans eğilimlerini, varyansı ve birbirleriyle olan korelasyonları ortaya çıararak ilgili karşılaştırmaları yapabilmeleri için öğrenci performans verilerini işleme fırsatına sahiptir. İşlenmiş veriler, veli ve öğrencilerin kendi beklentilerini karşılayabilecek okulları belirleyebilmeleri ve eğitim göreceği okulu seçme konusunda yardımcı olmaktadır. Bu açıdan bakıldığında, Yeni Zelanda hükümeti ürettiği öğrenci performans bilgilerinin içeriğini ve yararlılığını düzenleyerek hem bürokrasi hem de ebeveynler aracılığıyla okullarda performans ve piyasa hesap verebilirlik baskılarının oluşturulmasına izin verdiği anlaşılmaktadır.

\section{Tartıșma}

Türkiye'nin milli eğitimde merkezi sınav uygulamalarına bakıldığında, hazırlanması, uygulanması, puanlanması, sonuçlarının duyurulması ve 
kullanılması konusunda çok benzer yönlerinin olmasına karşın, özellikle üretilen performans bilgisinin içeriği, performans bilgisinin yayılması ve eğitimde kullanılmasına ilişkin önemli farklılıklara sahip olduğu görülmektedir. Diğer ülkeler anadil kullanımı, matematik ve yabancı dil gibi temel alanlardaki üst düzey bilişsel becerileri daha çok kısa cevap, açı uçlu ve alternatif ölçme araçlarını kullanarak yoklarken, Türkiye daha çok dersden öğrencileri sorumlu tutmakta, ve sadece çoktan seçmeli soruları kullanarak öğrenci kazanım düzeylerini ölçmeye çalışmaktadır. Türkiye' de ortaokul öğrencilerinin alan bilgisi performansları öğrenci bazında ve gerekli istatistiki analizleri de içeren sonuç raporları okullarla, ve web sayfası ve medya üzerinden kamuoyuyla paylaşılmaktadır (MEB, 2016; 2018a). Yükseköğretime geçiş sınavı sonuçları ise, öğrenci başarı sıralaması şeklinde öğrenci velilerine ve okullara bildirilmektedir. Öte taraftan ÖSYM öğrenci performanslarını okul veya program bazında genel bir anlayışla değerlendirmekte, öğrencilerin yerleşme durumlarını basit istatistiklerle özetleyerek medya ve web sayfası üzerinden kamuoyuna sunmaktadır (OECD, 2015; 2016; ÖSYM, 2018; 2019). Dolayısıyla, Türkiye'de merkezi sinavlar okul hesap verebilirliğine sınırlı düzeyde katkı sağlamaktadır. Öğrenci performans bilgisini diğer ülkelerde olduğu gibi daha çok öğrenci hesap verebilirliği için kullanmakta, okulların üst öğretim programlarına yerleştirilmesi, bursların dağıtılması gibi konularda öğrencilere ilişkin alınacak kararlarda kullanmaktadır.

Öğrencilerin eğitim sistemi içerisindeki ve sonucundaki menfeaatlere adil bir şekilde ulaşmaları için merkezi sınavların kullanılması oldukça önemli ve işlevseldir. Aynı şekilde, merkezi sınavlar öğretime ilişkin bir geribildirim sağlayarak özellikle okul yöneticileri ve öğretmenlerin öğretime ilişkin düşüncelerini, tutumlarını ve eylemlerini geliştirme, böylece okul motivasyonun ve kapasitesinin artırılmasına çok güçlü destek olmakta, böylece öğrenci kazanımlarının artırılmasına katkı sağlanmaktadır. Merkezi sınavların kapsadığı alanlar, kullanılan ölçme araçları, puanlanması, değerlendirilmesi ve sonuçlarının eğitim paydaşlarıyla paylaşılması, aynı zamanda eğitimde hesap verebilirliğin sağlanmasına sağladığı katkılar bir bütün olarak ele alındığında akademik performansı yüksek olan batı toplumlarının öğretim programı, öğretim etkinlikleri ile ölçme ve değerlendirmeyi çok iyi derecede entegre ettikleri 
ve işlettikleri anlaşılmaktadır. Bu en temelde eğitimde hesap verebilirlik anlayışının özünden beslenmektedir. Okullarla, öğretmenlerle veya okul müdürleriyle okuldan beklentileri olan eğitim paydaşları arasında kurulan hesap verebilirlik ilişkilerinde öğretim programı uygun ve doğru davranışa ilişkin performans standartlarını ortaya koymaktadır. Kurulan bu ilişkide standartlar, öğretme sorumluluğunu üstlenen öğretmen ve yöneticilerin öğretim etkinliklerini de standartların erişimine olanak sağlayacak öğretime ilişkin doğru tutum ve davranışların sergilenmesine, mesleki gelişime, motivasyon artışına ve işbirliğinin geliştirilmesine katkı sağlamaktadır. Öğretmenleri ve yöneticileri asıl zorlayıc güç ise, öğretim süreç ve sonuçlarının standartlara göre işleyip işlemediğinin sürekli olarak izlenilmesi ve performans bilgisinin üretilmesidir. Bu bilgi eğitim paydaşlarını okullara karşı daha da güçlendirmekte ve okullar üzerinde beklentilerin karşılanması yönünde baskı üretilmesine de olanak sağlamaktadır. Bu baskı gücü, başarılı performansa verilen ödülle veya düşük performansa uygulanan yaptırımlarla daha da pekiştirilmektedir. Dolayısıyla, akademik performansı yüksek eğitim sistemlerine sahip olan batı toplumları bu başarılarını öğretim standartları, öğretim etkinlikleri, performans ölçme ve değerlendirme ile gelişim ve destek hizmetlerinin güçlü bir entegrasyonuna borçludurlar. Öğrencilerin akademik performansını artırarak eğitimde etkililiği, verimliliği ve hatta adaleti sağlama amacında olan Türkiye eğitim sisteminde hesap verebilirlik anlayışını ilgili araç ve teknolojilerle önce geliştirilmeli ve sonra güçlendirmelidir. Bu kapsamda 21. yüzyıl becerilerine göre yeniden şekillendirilen ve yüksek düşünme becerilerinin kazandırılmasını önemseyen bir öğretim programı eşliğinde öğrenmenin uygun öğretim yöntem ve tekniklerle desteklenmesi, öğrenci performansının uygun ölçme araçlarıyla sürekli olarak izlenilmesi ve performans bilgisinin üretilmesi, aksayan süreçlerin belirlenerek çözüm yollarının üretilmesine imkan sağlayacak bir okul sürecinin geliştirilmesini hedeflemelidir. Bu bağlamda öğretmenlerin öğretim yöntem ve tekniklerine ilişkin kapasitelerinin artırılması yanı sıra, ölçme ve değerlendirmeyi öğrencilerin gelişimlerine destek olacak şekilde kullanabilme becerilerinin de artırılması en temel gereklilik olarak öne çıkmaktadır. Öte taraftan, öğrencilerin akademik performanslarının artırılması sadece okulların üstlenmesi gereken bir sorumluluk olarak görülmemeli, öğrencilerin de öğrenmenin sorumluluğunu üstlenmelerini 
sağlayacak hesap verebilirlik mekanizmalarından asla vazgeçilmemelidir. Öğrencilerin performansına bağlı ödüllere yer verilmesi gerektiği kadar yaptırımlara da eğitim sistemi içinde yer verilmelidir. Belirli nitelikleri kazanmış, gerekli bilişsel, duyusal ve psikomotor beceri standartlarına ulaşmış öğrencilerin kademeler arasında geçişine izin verilmeli, aksi halde öğrencilerin becerilerinin geliştirilmesi için gerekli tüm desteklerin sağlanması, aksi uygulamalarla kamuoyunda adalet duygusunun sarsılmasına, öğrencilerin öğrenmeye ilişkin olumsuz tutum takınmalarına imkan verilmemelidir.

$\mathrm{Bu}$ çalışmada elde edilen bulgular ve ulaşılan sonuçlara göre Türkiye'de merkezi sınavların doğası ve hesap verebilirlik maksatlı kullanımına ilişkin daha detaylı çalışmalara ihtiyaç vardır. Öğrencilerin performanslarına ilişkin üretilen ve kamuoyuna açıklanan bilginin zenginliği ve derinliğine ilişkin daha özel çalışmalara gerek olduğu görülmektedir. Bununla birlikte, performans bilgisinin yayımlanması ve yayın içeriği, aynı zamanda yayının kimler tarafından nasıl kullanıldığına ilişkin çalışmaların da olmadığı görülmektedir. Bu çalışmalar sadece Türkiye'de değil ilgili ülkelerde de çok nadirdir. Öğrenci performans bilgisinin üretilmesi, raporlanması ve öğrenci, okul, öğretmen ve okul müdürü hesap verebilirliğine nasıl katkı sağladı̆̆ı, eğitim paydaşlarının davranışlarını nasıl değiştirildiğine ilişkin daha çok çalışmaya ihtiyaç olduğu görülmektedir. Bu kapsamda, (i) merkezi sınavların öğretim programlarındaki beceri düzeylerini ne kadar iyi temsil ettiği, öğrencilerin üst düzey bilişsel becerilerini ne kadar ölçebildiği mevcut merkezi sınav uygulamaları üzerinden, (ii) merkezi sınav uygulamalarına ilişkin değerlendirme raporlarının içerikleri, öğretmen ve okul yöneticilerinin öğretim ortamlarına ilişkin karar ve uygulamalarında ne kadar katkı sağladığ 1 öğretmen ve okul yöneticilerinin tecrübelerine dayalı olarak, ve (iii) okulların performanslarına ilişkin hazırlanan raporlar okul yöneticilerinin öğretime ilişkin liderlik kapasitelerine ne derece katkı sağladığı okul müdürlerinin tecrübelerine dayanılarak incelenmelidir. Aynı şekilde, performasn raporları öğretmenlerin motivasyonlarını ve mesleki sermayelerine olan katkıları öğretmenlerin tecrübeleri üzerinden incelenmeli ve tartışılmalıdır. 


\section{EXTENDED ABSTRACT}

\section{National Examinations as an Accountability Technology: The Cases of Finland, Estonia and New Zealand \\ * \\ Coşkun Erdağ \\ Aksaray University}

Since the mid-80s, a great number of American, Asian and European nations have implemented test-based school accountability policy in education to invest in their human capital and produce a qualified workforce (Tan, 2010). Along with them, Turkey too has announced in the "2023 Education Vision" policy document to start implementing a testbased accountability policy, which covers the central measurement, monitoring and evaluation of students' performance according to the set national standards (Turkish National Ministry of Education [MEB], 2018). On the other hand, it is very likely that the concepts and practices of school accountability are not adequately discussed within the education system, and that a change to the student measurement and evaluation system without proper discussions will produce serious problems. In this context, understanding the accountability policies of the world communities with high achievements in education and discussing the basic concepts and practices will make important contributions to the establishment and management of the new student monitoring and evaluation system expected to be implemented in Turkey. In this respect, the aim of this study is first to determine and compare the western-style policies of national examinations with respect to their production, share and use in primary and secondary schools, and second to discuss the implications for Turkey and develop a policy guide for the use of national examinations in Turkey to ensure both accountability and improvement in the quality of student outcomes.

To this end, three Western countries, Finland, Estonia and NewZealand were systematically reviewed and compared based on the literature-derived framework that involves (i) how the student performance 
information is produced by national examinations, (ii) how this information is disseminated, and (iii) what it is used for in the education systems.

Found out that although central exam applications in Finland, Estonia and New Zealand are apparently very similar to those in Turkey, these countries are seriously diverging from Turkey, especially in terms of the content and nature of the performance information they produce, their dissemination, and their use. There is a common policy of examination among these top-performing nations to produce student performance information. They use paper and pen exams centrally developed, standardized based on the national curriculum, either norm or criterion referenced, testing students' high-level cognitive skills in first language, math, science and second language especially at the end of upper secondary schools, not primary schools. Rather than multiple choice questions, these countries focus on measuring students' high level cognitive skills such as comprehension, analysis, synthesis and problem solving by using short-answer, open-ended questions and alternative measurement tools such as oral presentation, interview, portfolio and task-based assessment. After its application, student performance information is generated based on the student responses scored and evaluated in a rigorous way according to predetermined criteria even by the central governments and by teachers under the control of the central government and strict guidance.

Performance information, aggregated or not, is shared in these countries with almost all educational stakeholders, and used mainly for student and school accountability purposes. In the reports on the schools, Finland and Estonia mainly summarize the quality of the school and the quality of the school context and the previous and current exam performances of the schools in general terms, so that the development of the schools is monitored. New Zealand, on the other hand, provides information on what schools contribute to students in terms of program standards, and also reveals the differences in student and school performance depending on student and school demographics. New Zealand, Finland and Estonia use the student performance information for the student-related decisions such as student certification or graduation, access to selective upper secondary education and tertiary institutions, 
awarding scholarships and financial aid, and job recruitment, thus they serve as a tool that provides equity among society. On the other hand, performance reports on student attainment in these countries are also intended to be used for school accountability. These countries share student performance information generated through centralised exams with relevant external stakeholders, media, students, parents, teachers and educational administrators. The feedback is addressed in the context of professional accountability, and it is intended to contribute to the development of teachers' motivations and capacity to teach, thus developing an effective learning environment and climate in schools and supporting schools and student learning. Unlike Finland and Estonia, New Zealand prefers market and performance-type school accountability approaches based on student performance information. New Zealand, after generating student performance information, posts it to relevant education stakeholders on their web pages and permits the public to access information for evaluation and monitoring of the development of school performance over time. Additionlly, the processed data helps parents and students to identify schools that can meet their own expectations and to choose the school to study in.

\section{Kaynakça / References}

Aydın, A., Erdağ, C., ve Taş, N. (2011). A comparative evaluation of PISA 2003-2006 Results in Reading Literacy Skills: An Example of Top-Five OECD Countries and Turkey. Educational Sciences: Theory \& Practice, 11(2), 651-673.

Aydın, A., Sarıer, Y. ve Uysal, Ş. (2012). The comparative assessment of the results of PISA Mathematical literacy in terms of socio-economic and socio-cultural variables. Education and Science, 37(164), 20-30.

Bae, S. (2018). Redesigning systems of school accountability: A multiple measures approach to accountability and support. Education Policy Analysis Archives, 26(8), 1-32. http://dx.doi.org/10.14507/epaa.26.2920

Ball, S. J. (1993). Education markets, choice and social class: The markets as a class strategy in the U.K. and the USA. British Journal of Sociology of Education, 14(1), 3-18. http://dx.doi.org/10.1080/0142569930140101

Ball, S. J., Junemann, C., ve Santori, D. (2017). Edu.net. globalisation and education policy mobility. Abingdon, New York: Routledge. 
Best, M., Knight, P., Lietz, P., Lockwood, C., Nugroho, D., ve Tobin, M. (2013). The impact of national and international assessment programmes on education policy, particularly policies regarding resource allocation and teaching and learning practices in developing countries. 05/05/2019 tarihinde https://research.acer.edu.au/ar_misc/16 adresinden erişilmiştir.

Datnow, A., ve Park, V. (2009). Conceptualizing policy implementation: Large-scale reform in an era of complexity. In G. Sykes, B. Schneider \& D. Plank (Eds.) Handbook on Education Policy Research (pp. 348-361). New York: Routledge Publishing.

De Wolf, I., ve Janssens, F. (2007). Effects and side effects of inspection and accountability in education: An overview of empirical studies. Oxford Review of Education, 33(3), 379-396. http://dx.doi.org/10.1080/03054980701366207

Dillon, S. (2011). Obama to waive parts of No Child Left Behind. New York Times (September, 22, 2011).

Directoraite of Research and Development [EARGED]. (2003). Üçüncü Uluslararası Matematik ve Fen Bilgisi Çalışması (TIMSS-1999)-Ulusal Rapor [Third international mathematics and science study (TIMSS-1999) - National Report]. 10/05/2019 tarihinde http://egitek.meb.gov.tr/dosyalar\%5Cdokumanlar\%5Culuslararasi/timss_1999_ulusal_raporu.pdf adresinden erişilmiştir.

Directoraite of Research and Development [EARGED]. (2004). Öğrenci Başartsinı Belirleme Programı (PISA-2003), Ulusal Rapor [Student achievement evaluation programme (PISA 2003) - National Report]. 10/05/2019 tarihinde http://egitek.meb.gov.tr/dosyalar/pisa/ PISA_2003_Ulusal_Nihai.pdf adresinden erişilmiştir.

Dorn, S. (2007). Accountability Frankenstein: Understanding and taming the monster. Charlotte, NC: Information Age Publishing.

Eurydice. (2009a). National testing of pupils in Europe: Objectives, organisation and use of results. Education, Audiovisual and Culture Executive Agency, European Commission.

Eurydice. (2009b). National testing of pupils in Europe: Objectives, organisation and use of results - Country level reports: Estonia. Education, Audiovisual and Culture Executive Agency, European Commission.

Figlio, D. ve Loeb, S. (2011). School accountability. Handbook of the Economics of Education, 3, 383-421. http://dx.doi.org/10.1016/B978-0-444-534293.00008-9 
Gable, A., ve Lingard, B. (2015). NAPLAN data: A new policy assemblage and mode of governance in Australian schooling. Policy Studies, 37(6), 568582.

Hanushek, E., ve Raymond, M. (2004). The effect of school accountability systems on the level and distribution of student achievement. Journal of the European Economic Association, 2(2-3), 406-415. http://dx.doi.org/$10.1162 / 154247604323068096$

Hargreaves, A., Earl, L., Moore, S., ve Manning, S. (2001). Learning to change. Teaching beyond subjects and standards. San Francisco: Jossey-Bass.

Harris, D., ve Herrington, C. (2006). Accountability, standards, and the growing achievement gap: Lessons from the past half-century. American Journal of Education, 112(2), 209-238. http://dx.doi.org/10.1086/498995

Holmstrom, B., ve Costa, J. R. (1986). Managerial incentives and capital management. The Quarterly Journal of Economics, 101(4), 835-860.

Joshi, D. ve Smith, W. (2012). Education and inequality: Implications of the World Bank's Education Strategy 2020. In Wiseman, A. \& Collins, C. (Eds.), Education strategy in the developing world: Revising the World Bank's education policy (pp. 173-202). United Kingdom: Emerald Publishing. http://dx.doi.org/10.1108/S1479-3679(2012)0000016013

Kane, T. J. ve Staiger, D. O. (2002). The Promise and Pitfalls of Using Imprecise School Accountability Measures. Journal of Economic Perspectives, 16 (4), 91-114.

Klees, S. J. (2008). A quarter century of neoliberal thinking in education: Misleading analyses and failed policies. Globalisation, Societies and Education, 6(4), 311-348.

Lee, J., ve Wong, K. K. (2004). The impact of accountability on racial and socioeconomic equity: Considering both school resources and achievement outcomes. American Educational Research Journal, 41(4), 797-832. doi:10.3102/00028312041004797

Levin, H. M. (1974). A conceptual framework for accountability in education. The School Review, 82(3), 363-391.

Lincove, J. (2009). Are markets good for girls? The World Bank and neoliberal education reforms in developing countries. The Whitehead Journal of Diplomacy and International Relations, X(1), 19-35. 
Major C. ve Savin-Baden, M. (2010). An Introduction to qualitative research synthesis: Managing the information explosion in social science research. London: Routledge.

McDonnell, L., ve Elmore, R. (1987). Getting the job done: Alternative policy instruments. Educational Evaluation and Policy Analysis, 9(2), 157-184. http://dx.doi.org/10.3102/01623737009002133

McNeil, M., ve Klein, A. (2011). Obama outlines NCLB flexibility: Plan waves cornerstone provisions of law. Education Week, 31(5), 1, 20-22.

Milgrom, P., ve Roberts, J. (1988). An economic approach to influence activities in organizations. American Journal of Sociology, 94, 154-179.

Mundy, K. (2006). Education for all and the new development compact. Review of Education, 52, 23-48.

Noblit, G.W. and Hare, R.D. (1988) Meta-ethnography: Synthesizing qualitative studies. Sage Publications, Newbury Park.

O'Day, J. (2002). Complexity, accountability and school improvement. Harvard Educational Review, 72 (3), 293-329.

Olmedo, A., ve Wilkins, A. (2017). Governing through parents: A genealogical enquiry of education policy and the construction of neoliberal subjectivities in England. Discourse: Studies in the Cultural Politics of Education, 38(4), 573-589.

Robertson, S. L. (2015). What teachers need to know about the 'global education reform movement. In G. Little (Ed.), Global education 'reform'. Building resistance and solidarity (pp. 10-17).Croydon: Manifesto Press.

Rothstein, R., Jacobsen, R., ve Wilder, T. (2008). Grading education: Getting accountability right. NY: Teachers College Press and the Economic Policy Institute.

Sahlberg, P. (2016). The global educational reform movement and its impact on schooling. In (K. Mundy, A. Green, B. Lingard, \& A. Verger Eds.), The handbook of global education policy (p.128-144). West Sussex: WileyBlackwell.

Smith, W., ve Rowland, J. (2014). Parent trigger laws and the promise of parental voice. Journal of School Choice, 8(1), 94-112.

Springer, M. G. (2008). The influence of an NCLB accountability plan on the distribution of student test score gains. Economics of Education Review. doi: 10.1016/j.econedrev.2007.06.004 
Stecher, B., ve Kirby, N. (2004). Organizational improvement and accountability: Lessons for education from other sectors. Rand Cooporation. 10/05/2019 tarihinde http://www.rand.org/content/dam/rand/pubs/ monographs/2004/RAND_MG136.pdf adresinden erişilmiştir.

Supovitz, J. (2009). Can high stakes testing leverage educational improvement? Prospects from the last decade of testing and accountability reform. Journal of Educational Change, 10, 211-227. http://dx.doi.org/10.1007/s10833-009-9105-2

Tan, Sophia HueyShan. (2010). Singapore's Educational Reforms: The Case for Un-Standardizing Curriculum and Reducing Testing. AASA Journal of Scholarship and Practice, 6 (4), 50-58.

Tobin, M., Lietz, P., Nugroho, D., Vivekanandan, R., ve Nyamkhuu, T. (2015). Using large-scale assessments of students' learning to inform education policy: Insights from the Asia-Pacific region. Melbourne: ACER and Bangkok: UNESCO.

Milli Eğitim Bakanlığı [MEB] (2018) Mutlu çocuklar güçlü Türkiye: 2023 eğitim vizyonu. 10/05/2019 tarihinde http://2023vizyonu.meb.gov.tr/ doc/2023_EGITIM_VIZYONU.pdf adresinden erişilmiştir.

Türkoğlu, M.E. (2015). Öğretmen hesap verebilirlĭği: Özel bir okulda durum çalışması. Dissertation Thesis, Eskişehir Osmangazi Üniversitesi, Eskişehir Turkey. 10/05/2019 tarihinde http://openaccess.ogu.edu.tr:8080/ xmlui/-bitstream/handle/11684/363/10022484.pdf.pdf?sequence $=1 \&$ isAllowed $=y$ adresinden erişilmiştir.

Verger, Antoni; Lluís Parcerisa ve Clara Fontdevila (2018): The growth and spread of large-scale assessments and test-based accountabilities: a political sociology of global education reforms, Educational Review. https://doi.org/10.1080/00131911.2019.1522045

Woessman, L. (2004). The effect heterogeneity of central exams: Evidence from TIMSS, TIMSS-Repeat and PISA. CESifo Working Paper No. 1330.

Woessman, L. (2007). International evidence on school competition, autonomy, and accountability: A review. Peabody Journal of Education, 82(23), 473-497. http://dx.doi.org/10.1080/01619560701313176

Crooks, Terry (2011). Assessment for learning in the accountability era: New Zealand. Studies in Educational Evaluation, 37, 71-77.

Delil, A. ve Tetik, B. Y. (2015). 8. sinıf merkezi sinavlardaki matematik sorularının TIMSS-2015 bilişsel alanlarına göre analizi. CBÜ Sosyal Bilimler Dergisi, 13 (4), 165-184. 
Incikabi, L., Kurnaz, M. A., ve Pektas, M. (2013). An investigation of mathematics and science questions in entrance examinations for secondary education institutions in Turkey. Journal of Baltic Science Education, 12(3), 352-364.

Koç, H.; Sönmez, Ö. F. ve Çiftçi, T. (2013). ÖSS, YGS Ve LYS sınavlarındaki coğrafya sorularının bloom taksonomisi bilişsel alan düzeyi açısından analizi. Karadeniz Araştırmaları, 36, 257-275.

MEB (2016). Millî Ĕ̆itim Bakanlı̆̆ı merkezî sistem sınav yönergesi. 10/05/2019 tarihinde http://mevzuat.meb.gov.tr/dosyalar/1790.pdf adresinden erişilmiştir.

MEB (2018). Millî Ĕ̆itim Bakanlığı ortaöğretime geçiş yönergesi. 10/05/2019 tarihinde https://www.meb.gov.tr/meb_iys_dosyalar/2018_03/26191912_yonerge.pdf adresinden erişilmiştir.

MEB (2018a). 2018 Liselere geçiş sistemi (LGS): Merkezi sinavla yerleşen öğrencilerin performansi. 10/05/2019 tarihinde http://www.meb.gov.tr/meb_iys_dosyalar/2018_12/17094056_2018_lgs_rapor.pdf adresinden erişilmiştir.

MEB (2018b). Ortaöğretime geçiş tercih ve yerleştirme kilavuzu 2018. 11/05/2019 tarihindehttps://odsgm.meb.gov.tr/meb_iys_dosyalar/2018_06/ 29113510_2018_YILI_TERCYH_VE_YERLEYTYRME_KILAVUZU.pdf adresinden erişilmiştir.

New Zealand Ministry of Education [NZMoE] (2010) OECD Review on evaluation and assessment frameworks for improving school outcomes: New Zealand Background Report

New Zealand Qualifications Authority (NZQA) (2019). Understanding NCEA, 10/05/2019 tarihinde https://www.nzqa.govt.nz/ncea/understandingncea/ adresinden erişilmiştir.

NZQA (2017a). NZQA examination development process. 10/05/2019 tarihinde https://www.nzqa.govt.nz/assets/qualifications-and-standards/qualifications/ncea/NZQA-Examination-Development-Process.pdf adresinden erişilmiştir.

NZQA (2017b). NZQA examination marking process. 10/05/2019 tarihinde https://www.nzqa.govt.nz/assets/qualifications-and-standards/qualifications/ncea/NZQA-Examination-Marking-Process.pdf adresinden erişilmiştir. 
NZQA (2018). Annual report on NCEA and New Zealand Scholarship data and statistics (2017), 10/05/2019 tarihinde https://www.nzqa.govt.nz/assets/About-us/Publications/stats-reports/ncea-annual-report2017.pdf adresinden erişilmiştir.

NZQA (2019a). NZQA NCEA external assessment: Grade score marking, 10/05/2019 tarihinde https://www.nzqa.govt.nz/ncea/ncea-examsand-portfolios/external/grade-score-marking/ adresinden erişilmiştir.

NZQA (2019b). NCEA results, 10/05/2019 tarihinde https://www.nzqa.govt.nz/ncea/ncea-results/ adresinden erişilmiştir.

OECD (2013). PISA 2012 results: What students know and can do - student performance in mathematics, reading and science (Volume I), PISA, OECD Publishing. http://dx.doi.org/10.1787/9789264201118-en

OECD (2015). Education at a glance 2015: OECD indicators, OECD publishing. http://dx.doi.org/10.1787/eag-2015-en

OECD (2016). PISA 2015 results (Volume I): Excellence and equity in education, PISA, OECD Publishing, Paris. http://dx.doi.org/10.1787/9789264266490-en

Öğrenci Seçme ve Yerleştirme Merkezi [ÖSYM] (2018). 2018 YKS değerlendirme raporu. 11/05/2019 tarihinde https://dokuman.osym.gov.tr/pdfdokuman/2018/GENEL/ YKSDegrapor06082018.pdf adresinden erişilmiştir.

ÖSYM (2019a). Yükseköğretim kurumlari sınav temel yeterlilik testi (TYT). 11/05/2019 tarihinde https://dokuman.osym.gov.tr/pdfdokuman/2018/ YKS/TYT_01072018.pdf adresinden erişilmiştir.

ÖSYM. (2019). 2019 yükseköğretim kurumlari sinavi (YKS) kilavuzu. 11/05/2019 tarihinde https://dokuman.osym.gov.tr/pdfdokuman/2019/YKS/kilavuz_11022019.pdf adresinden erişilmiştir.

\section{Kaynakça Bilgisi / Citation Information}

Erdağ, C. (2019). Bir hesap verebilirlik teknolojisi olarak merkezi sınavlar: Finlandiya, Estonya ve Yeni Zelanda örnekleri. OPUS-Uluslararası Toplum Araştırmaları Dergisi, 14(20), 1528-1563. DOI: 10.26466 /opus.592335 